\title{
5. MAGNETOSTRATIGRAPHIC AND BIOSTRATIGRAPHIC SYNTHESIS, LEG 117, ARABIAN SEA 1
}

\author{
S. A. Spaulding, ${ }^{2}$ J. Bloemendal, ${ }^{3}$ A. Hayashida, ${ }^{4}$ J.O.R. Hermelin, ${ }^{5}$ K. Kameo, ${ }^{6}$ D. Kroon, ${ }^{7}$ C. A. Nigrini, ${ }^{8}$ \\ T. Sato, ${ }^{7}$ T.N.F. Steens, ${ }^{9}$ T. Takayama, ${ }^{10}$ and S. R. Troelstra ${ }^{9}$
}

\begin{abstract}
During the late early Miocene to early middle Miocene, the Owen Ridge was uplifted to a sufficient height as to be above the realm of turbidite deposition. Monsoonal-induced upwelling appears to have been initiated during the Miocene. On the Oman Margin, the effect of upwelling on the microplankton was established by the middle Miocene. However, the effects of upwelling on the Owen Ridge region were not realized until later, in the early late Miocene. A transition in the upwelling regime took place between the Pliocene and Pleistocene. While the Miocene and Pliocene sediments are dominated by the siliceous component, the Pleistocene sediments seem to be dominated by the calcareous component.
\end{abstract}

\section{INTRODUCTION}

During Leg 117, 25 holes were drilled at 12 sites in the western portion of the Arabian Sea (Fig. 1). Over $4300 \mathrm{~m}$ of highquality core was recovered from a continuum of water depths ranging from above to below the points where the oxygen-minimum zone (OMZ) impinges on the seafloor. Because this portion of the Arabian Sea experiences upwelling of colder, nutrient-enriched waters during the months coincident with the summer monsoon, an examination of the microfossil content of the sediments of different ages and different locations within the region provides important information about the Neogene tectonic history, paleoceanography, and paleoproductivity in this portion of the Indian Ocean. The magnetostratigraphic and biostratigraphic assignments for Leg 117 sediments are shown in Figure 2. In several intervals, it was impossible to make specific zonal assignments due to the lack of some typical tropical zonal markers. These marker species will be discussed in the following section.

\section{PALEOMAGNETIC AND MICROFOSSIL SUMMARY}

\section{Magnetostratigraphy}

The magnetostratigraphy of Leg 117 sediments was determined using inclination data of discrete samples (Hayashida and Bloemendal, this volume). Usually two specimens per section $(1.5 \mathrm{~m})$ were obtained from the sediments recovered by the Advanced Hydraulic Piston Corer (APC) or Extended Core Barrel (XCB) technique at Sites 720 through 731 . Because the sedi-

\footnotetext{
${ }^{1}$ Prell, W. L., Niitsuma, N., et al., 1991. Proc. ODP, Sci. Results, 117: College Station, TX (Ocean Drilling Program).

2760 Magazine Street, New Orleans, LA 70130, U.S.A.

3 Graduate School of Oceanography, University of Rhode Island, Narragansett, RI 02882, U.S.A.

${ }^{4}$ Laboratory of Earth Science, Doshisha University, Kyoto 602, Japan. den.

5 Department of Geology, University of Stockholm, S-106 91 Stockholm, Swe-

6 Technical Research Center, Teikoku Oil Co., Tokyo 157, Japan.

7 Grant Institute of Geology, University of Edinburgh, Edinburgh EH9 3JW, Scotland, United Kingdom.

8510 Papyrus Drive, La Habra Heights, CA 90631, U.S.A.

${ }^{9}$ Institute of Geology, Free University, N1-1007 MC Amsterdam, The Netherlands.

${ }_{10}$ Department of Geology, Kanazawa University, Kanazawa 920, Japan.
}

ments at Site 729 were drilled with the Rotary Core Barrel (RCB), no magnetic measurements were made. Magnetic measurements were made on a shipboard flux-gate magnetometer and a shorebased cryogenic magnetometer. The weak and relatively soft magnetic character of the sediments partially restricted the quality and resolution of the magnetostratigraphy, especially of the intervals below approximately 200 mbsf. Gas expansion observed at some Oman Margin sites significantly affected the paleomagnetic record.

The polarity zones, usually identified in the uppermost $200 \mathrm{~m}$ of sediment, were assigned to the polarity time scale of Berggren et al. (1985) by referring to the biostratigraphic data. The magnetic record of the Owen Ridge sites (721 and 722) was correlated from the Brunhes $(\mathrm{C} 1)$ to Chronozone $5(\mathrm{C} 3 \mathrm{~A})$ or 6 $(\mathrm{C} 3 \mathrm{Ar})$. At these sites, however, polarity intervals of approximately, or less than, $10^{5} \mathrm{yr}$ in duration, such as the Olduvai (C2), Kaena (C2A-1), and Mammoth (C2A-2) Subchronozones, were not detected. On the Oman Margin, clear reversal records were observed from the Brunhes (C1) to the Olduvai Subchronozone (C2) at Site 724, and to the Gauss Chronozone (C2A) at Site 727. The Olduvai Subchronozone (C2) was missing at Site 728. Nevertheless, the interval from 50 to $200 \mathrm{mbsf}$ at this site provided the best reversal stratigraphy from the Gauss $(\mathrm{C} 2 \mathrm{~A})$ to the Gilbert (C3) Chronozones.

\section{Calcareous Nannofossils}

The calcareous nannofossil zonation of Martini (1971) was used during Leg 117 for the Miocene and Pliocene sediments. A modified Pleistocene zonation (Takayama and Sato, 1987) was used for the Quaternary sediments (Spaulding, this volume) and further modified by Sato et al. (this volume). Based upon the reexamination of calcareous nannofossils from the Pliocene-Pleistocene boundary stratotype at Le Castella, Italy, the FAD (first appearance datum) of Gephyrocapsa caribbeanica is used as a micropaleontological approximation of the Pliocene-Pleistocene boundary for this leg (T. Takayama, pers. comm., 1988).

Calcareous nannofossils are common to abundant in nearly every sample studied. A few samples had rare or few specimens and a few others were entirely barren of nannofossils. Preservation ranges from poor to good with most samples falling somewhere in the moderate category. In some of the lower Miocene sediments asteroliths and sphenoliths are heavily overgrown. Some of the typical tropical Miocene and Pliocene marker species are missing or too rare to be stratigraphically useful. These include representatives of the ceratoliths, amauroliths, astero- 


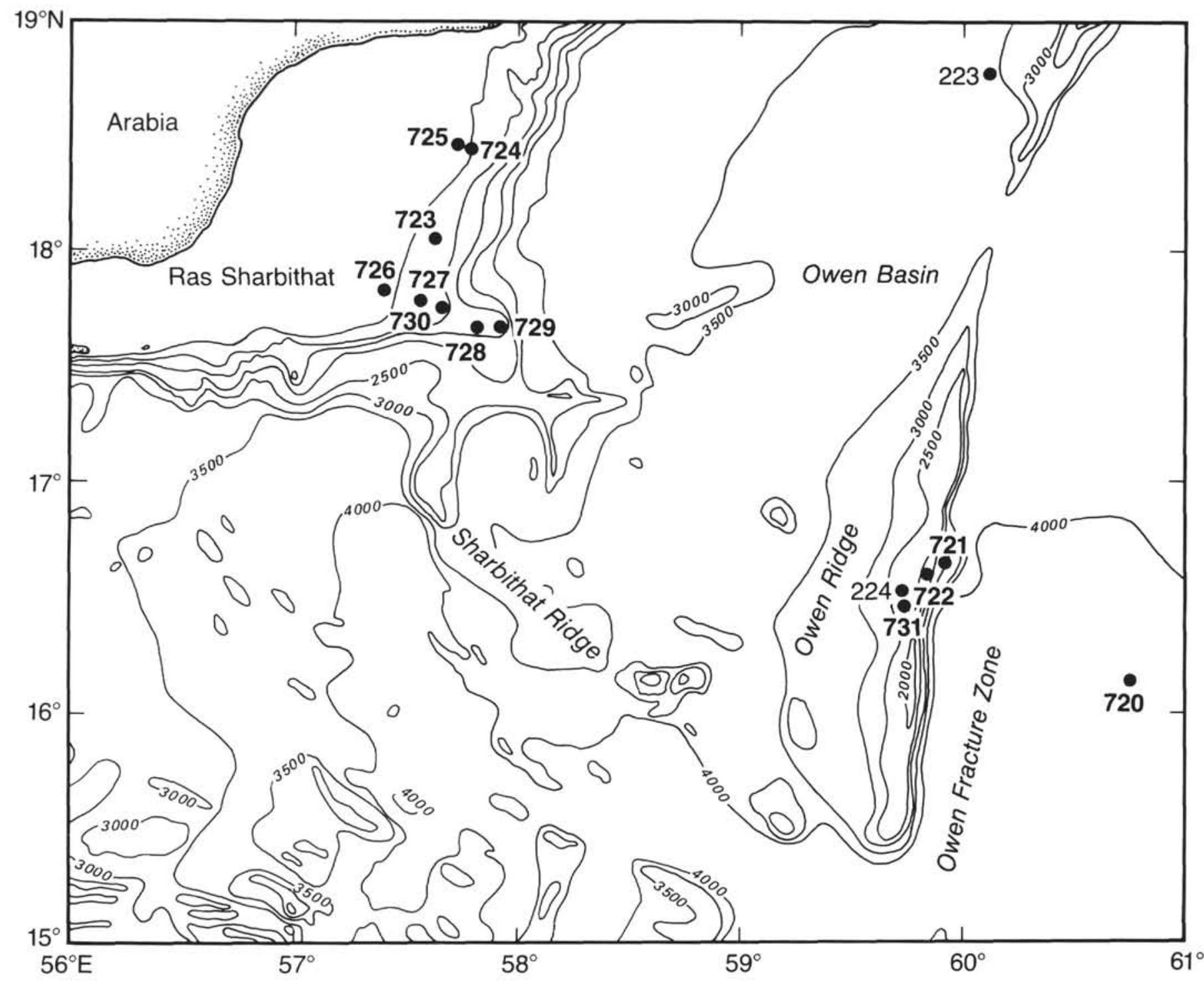

Figure 1. Locations of sites drilled during Leg 117.

liths, and helicosphaerids. The diversity of the nannofossils seems to be somewhat lower than one would expect from a tropical region located from $16^{\circ} \mathrm{N}$ to $18^{\circ} \mathrm{N}$. There seems to be no doubt that the upwelling waters in this part of the Indian Ocean noticeably affect the composition of the nannofossil assemblages. A few reworked Cretaceous and Tertiary specimens were found in over $60 \%$ of the samples studied from the Oman Margin. Because the oldest sediments recovered are early Miocene in age, it is suggested that these Cretaceous and Tertiary specimens were carried by the southwest monsoon winds that are known to supply quite significant amounts of clay to the region.

Overall, the calcareous nannofossils provide the most consistently reliable biostratigraphic zonations for Leg 117. Thirtyfour nannofossil datums are recognized in the Quaternary, Neogene, and uppermost Paleogene sediments. Six of these datums are new and can be found in Sato et al. (this volume).

\section{Planktonic Foraminifers}

Planktonic foraminifers range from barren or few to abundant at each site. The zonation of Blow (1969) was adhered to as closely as possible during this leg. Some zonal marker species for the Pliocene and Pleistocene are missing or are very rare. Be- cause the evolutionary series of Globorotalia tosaensis to $G$. truncatulinoides is missing in the upper Pliocene to lower Pleistocene sediments, the N21/N22 zonal boundary was approximated by using the LAD (last appearance datum) of Globigerinoides obliquus. Also, because Globorotalia margaritae and Globigerinoides fistulosus are rare the zonation of the Pliocene sediments is hindered. Thirty-two planktonic foraminiferal datums are recognized during this leg.

The planktonic foraminifers from Owen Ridge Sites 721 and 722 provide a complete biostratigraphy. At the other Owen Ridge site (731), the planktonic foraminifers are rare and show signs of substantial dissolution. The sites on the Oman Margin (723730 ), in general, contain planktonic foraminifers which have been reduced in numbers as a result of dissolution, diagenesis, or a reduction in their ecological niches.

\section{Benthic Foraminifers}

Shipboard analyses showed that benthic foraminifers ranged from barren to abundant at each site. Benthic foraminifers occur sporadically and range from poorly- to well-preserved. The foraminifers in the limestone recovered at Sites 726 and 729 are recrystallized but their presence provides the only age control for 


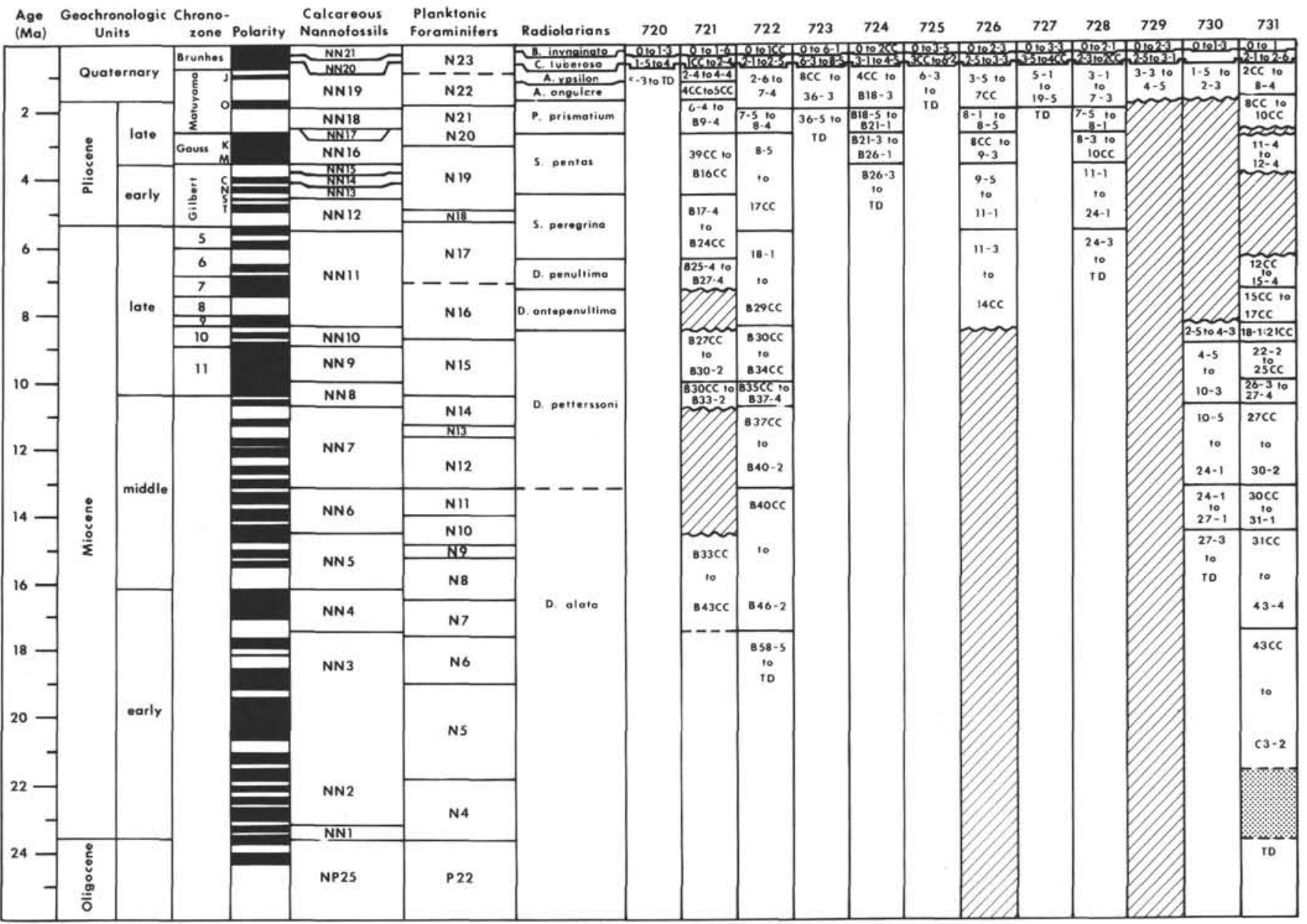

Figure 2. Summary of biostratigraphic assignments for Neogene and Quaternary sediments, ODP Leg 117. Correlation of calcareous nannofossil, planktonic foraminiferal, and radiolarian zones after Berggren et al. (1985). In chronozone column: $\mathrm{J}=\mathrm{Jaramillo}, \mathrm{O}=\mathrm{Olduvai,} \mathrm{K}=\mathrm{Kaena}, \mathrm{M}=$ Mammoth, $\mathrm{C}=$ Cochiti, $\mathrm{N}=$ Nunivak, $\mathrm{S}=$ Sidufjall, $\mathrm{T}=$ Thvera. Cross-hatch areas represent hiatuses. Stippled area represents interval of sediments with no planktonic microfossils. Numbers in columns refer to core and/or section numbers. Single numbers indicate core number (e.g., $1=$ Core 1 for that hole). Hyphenated numbers represent core number followed by section number (e.g., $3-5=$ Section 5 of Core 3 for that hole). TD = total depth for that hole. Calcareous nannofossil zonation after Martini (1971); planktonic foraminiferal zonation after Blow (1969); radiolarian zonation after Sanfilippo et al. (1985). For Sites 721, 722, 724, and 731, results from two holes were combined to produce a composite section; the letter preceding the core number indicates the hole. All others are taken from the A hole at each site.

these units. When the amount of phosphoritized teeth and vertebrae in a sample increases, there seems to be a concomitant increase in the benthic foraminiferal diversity, but a decrease in the preservation state. The benthic foraminifers have been studied in detail from Sites 725, 726, and 728 from the Oman Margin.

\section{Radiolarians}

Significant numbers of radiolarians were recovered from the three Owen Ridge sites $(721,722$, and 731) and from three of the sites located on the continental margin of Oman $(723,728$, and 730). Sparse radiolarians were found in sediments recovered from the solitary Indus Fan site (720) and from four sites on the Oman Margin (724, 725, 726, and 727). One site located on the Oman Margin was completely barren of siliceous microfossils (729). The preservation of radiolarians ranges from specimens which are coated with pyrite to ones that are well-preserved.

The radiolarian zonations used are those of Nigrini (1971) and Riedel and Sanfilippo (1978). Some of the typical tropical radiolarian species are missing from the Leg 117 sediments. These include Pterocanium prismatium and Spongaster pentas. Conversely, several taxa which are not usually indigenous to tropical sediments were observed. A few of these are recorded for the first time from the Indian Ocean. Some of these atypical species are known from areas affected by the Peruvian and East Pacific upwelling currents (Nigrini, 1968), and others are abundant in temperate areas (e.g., Crozet Basin) but are rarely members of tropical assemblages. Sixty radiolarian datums are recognized.

\section{QUATERNARY AND NEOGENE}

\section{Indus Fan (Site 720)}

Abundant calcareous nannofossils, and planktonic and benthic foraminifers with moderate to good preservation are found in the pelagic sediments (foraminifer-bearing nannofossil oozes, 0-17.22 mbsf). Rare radiolarians, which exhibit some degree of dissolution, are found in some samples down to $28.6 \mathrm{mbsf}$. Turbiditic sediments (silty clays, silts, silty sands, and sands) are present from 17.22 to $414.3 \mathrm{mbsf}$. As is not unexpected from sediments of this type, only two polarity reversals were recorded and only one of which has much confidence. The boundary between the Brunhes and Matuyama Chronozones (Chron C1N/ $\mathrm{C} 1 \mathrm{R})$ was recognized and correlated with the calcareous nanno- 
fossil stratigraphy. Below a depth of $\mathbf{3 0 0}$ mbsf the absence of biostratigraphic constraints coupled with the lack of sufficient numbers of stable samples prohibits the correlation of the recovered sediments with the polarity reversal time scale.

The turbiditic sediments contain lower concentrations of calcareous nannofossils, planktonic and benthic foraminifers, and radiolarians. Quaternary calcareous nannofossil Zones NN19 to NN21 and planktonic foraminiferal Zones N22 and N23 are recognized. No biostratigraphic zonation based on radiolarians is possible because the assemblage is composed primarily of longranging Spumellaria. However, robust specimens and diverse assemblages from two pelagic layers within the turbidite sequences in Core 117-720A-30X suggest a cool-water affinity based on the presence of Eucyrtidium acuminatum and Pterocanium praetextum eucolpum.

Braarudosphaera bigelowii, a typical shallow-water calcareous nannofossil (Martini, 1967; Takayama, 1972), and Ammonia beccarii, a shallow-water benthic foraminifer (Murray, 1976), are found in samples from the turbiditic sediments.

Reworked Cretaceous and Tertiary calcareous nannofossils and Nuttalloides truempyi, a Late Cretaceous to Eocene benthic foraminifer (van Morkhoven et al., 1986), are also found in several turbiditic samples.

The Quaternary sedimentary sequence at Site 720 records fan deposition with some intercalated pelagic oozes (less than $10 \mathrm{~m}$ thick). These thin oozes are reflective of changes in turbidite flux which may be related to changes in sea level.

\section{Owen Ridge (Sites 721, 722, and 731)}

\section{Quaternary}

The pelagic Quaternary sequences at each of these three sites are comprised primarily of calcareous nannofossil ooze. The thickness of the Quaternary sediments is relatively consistent over the length of the Owen Ridge. Pleistocene to Holocene sediments range from $63.50 \mathrm{~m}$ thick at Sites 721 and 722 to $84.20 \mathrm{~m}$ thick at Site 731. Calcareous nannofossils are abundant with moderate to good preservation in the Quaternary oozes. Planktonic and benthic foraminifers are common to abundant, diverse, and well-preserved. Radiolarians are well-preserved, robust, and abundant at Sites 721 and 722 and are few to common with moderate preservation at Site 731 .

\section{Neogene}

Like the Quaternary sediments, the Pliocene sequences on the Owen Ridge also consist primarily of nannofossil ooze. Complete Pliocene sequences were recovered from Sites 721 and 722. However, based on the radiolarian zonation at Site 731, an unconformity is recognized in the upper Pliocene sediments. This resulted in the elimination of all of the lower Pliocene and a portion of the lowermost upper Pliocene sediments. Calcareous nannofossils are abundant, and planktonic and benthic foraminifers are common to abundant. Radiolarians are abundant in nearly every Pliocene sample.

During the late Miocene, nannofossil ooze was the dominant lithology deposited over the Owen Ridge. Increased amounts of biogenic silica are present in the middle to upper Miocene nannofossil oozes and chalks at all three sites. Benthic foraminifers at Site 722 are commonly pyritized at levels coincident with increased amounts of biogenic silica.

An extensive middle Miocene hiatus is present at Site 721 . Uppermost lower Miocene deposition at Sites 721 and 731 and lower to middle Miocene sediments at Site 722 consist of clastic turbidites of silty clays and muds. Preservation of microfossils in the turbiditic sediments is significantly poorer than in the overlying pelagic sediments. Planktonic foraminifers and radio- larians are absent from the lower Miocene and most of the middle Miocene sediments at Site 721. Few benthic foraminifers with poor preservation are found in the turbiditic sequences. Calcareous nannofossils in the lower Miocene and lowermost middle Miocene sediments are abundant but have poor preservation which is manifested as heavy calcitic overgrowths on the sphenoliths, asteroliths, and Cyclicargolithus floridanus. Lowermost Miocene sediments at Site 731 are barren of all microfossils.

$$
\text { Oman Margin (Sites 723-730) }
$$

\section{Quaternary}

Holes drilled at Sites 723, 724, 726, 727, and 728 recovered complete Quaternary sequences. The Pleistocene sediments at Sites $723,727,728,729$, and 730 are nannofossil oozes while the Pleistocene sediments from Sites 724,725 , and 726 are more hemipelagic in nature (nannofossil ooze to sand-silt-clay to calcareous clayey silts to nannofossil foraminifer-rich mud). Sites 724,725 , and 726 are closer to land, and therefore, it is not surprising that they have a more dominant terrigenous fraction. Abundant calcareous nannofossils with moderate to good preservation are present in all of the Pleistocene to Holocene sediments on the Oman Margin. Coccolithus pelagicus and C. crassipons, typical cold-water taxa, are present in large numbers in the lower Pleistocene sediments from Sites 723, 724, 726, 727, and 728 .

Hyalinea balthica, a cool-water benthic foraminifer, is present throughout the Quaternary sediments at Sites 723, 724, and 725 . High relative abundances of the planktonic foraminifers Globigerina bulloides, Neogloboquadrina dutertrei, Globorotalia menardii, and Globigerinita glutinata indicate that upwelling conditions existed at Site 723 during the Pleistocene. The high $\mathrm{P} / \mathrm{B}$ (planktonic/benthic) foraminiferal ratio and the stable assemblage composition of benthic foraminifers suggest that no significant changes in the water depth have occurred during the Pleistocene at Site 727. The P/B ratio together with the benthic foraminiferal faunal composition suggest that during the Pleistocene Site 729 was located in the upper middle bathyal zone.

Radiolarians have the most sporadic occurrence of any of the microfossils studied in detail. At Site 723 all of the typical tropical Pleistocene radiolarian zonal markers are missing. However, the assemblage in Sample 117-723A-5H-CC contains the Arabian Upwelling Assemblage of Johnson and Nigrini (1982). At Site 725 the uppermost 10 cores are barren of radiolarians, but samples below 95.3 mbsf have a significant siliceous fauna and flora which include radiolarians, sponge spicules, and diatoms. Again, some tropical marker species are missing. However, a more diverse fauna is found at Site 725 than at Site 724. Dictyophimus infabricatus, an upwelling form found in the eastern equatorial Pacific, is relatively abundant at Site 725 .

\section{Neogene}

Upper Pliocene sediments at Site 723 have high relative abundances of planktonic foraminifers Globigerina bulloides, Neogloboquadrina dutertrei, Globorotalia menardii, and Globigerinita glutinata which indicate upwelling conditions existed at this site during the late Pliocene.

Few calcareous nannofossils with poor preservation are present throughout much of the upper Pliocene calcareous clayey silts at Site 724. Zones NN17 and NN18 have been combined due to the absence of the low-latitude marker species, Discoaster pentaradiatus. Low-diversity radiolarian assemblages are characteristic of most of the upper Pliocene sediments at Site 724 .

During the late Pliocene silty clays to nannofossil ooze to chalk alternating with foraminifer-rich clayey silts were deposited at Site 726. Calcareous nannofossil Zones NN16 and NN17 
were combined in the absence of the low-latitude marker species, Discoaster surculus. Planktonic foraminifers are rare and exhibit poor preservation.

Biogenic opal is a common component of the marly nannofossil ooze which was deposited at Site 728 during the late Pliocene. This is indicative of increased paleoproductivity during these times. Hiatuses at Sites 729 and 730 preclude the recognition of upper Pliocene sediments.

Coccolithus pelagicus and C. crassipons, typical cold-water taxa, are abundant in the upper Pliocene sediments at Sites 723, $724,726,727$, and 728. Hyalinea balthica, a benthic foraminifer found in cold water masses, is present in the upper Pliocene sediments at this Sites 724 and 728. The genus Helicosphaera is abundant in upper Pliocene samples from Sites 723, 724, 725, and 728 . This genus is thought to have preferred regions of upwelling (Perch-Nielsen, 1985).

Calcareous clayey silts were also deposited at Site 724 during the early Pliocene. These contain abundant calcareous nannofossils and common planktonic foraminifers. Fewer radiolarians are present than in the upper Pliocene sediments from this site. Ammonia beccarii, a benthic foraminifer which today is found in waters less than $350 \mathrm{~m}$ (Murray, 1976) is found in the lower Pliocene sediments at Sites 724 and 728 .

The lower Pliocene sediments at Site 726 are similar to those deposited during the late Pliocene. Calcareous nannofossil Zones NN12-NN15 were combined at Sites 726 and 728 because the marker species are missing. Planktonic foraminiferal Zones N19 through N21 were also combined for the same reason. The lower Pliocene sediments at Site 728 contain common biogenic opal. Hyalinea balthica, a cold-water benthic foraminifer, is present in the uppermost lower Pliocene sediments at Site 728.

Lower Pliocene sediments are not present at Sites 729 and 730 due to hiatuses at these sites.

During the latter part of the late Miocene, rare to abundant calcareous nannofossils were deposited at Site 726 . The benthic foraminifer, Bolivina seminuda, comprises up to $95 \%$ of the assemblage. A hiatus at Site 726 precludes the recognition of lowest upper Miocene sediments.

Common biogenic opal is present in upper Miocene sediments at Site 728. Planktonic foraminifers are rare to few, which results in the combination of Zones N16 and N17. The dominance of thick-walled Globorotalia tumida tumida indicates that dissolution has affected the planktonic foraminiferal assemblage. The dissolution process may have been affected by an intensified or expanded oxygen-minimum zone during this time.

A hiatus at Site 730 removed the uppermost upper Miocene sediments. Siliceous microfossils are found in the upper Miocene sediments that are present at this site.

Site 730 is the only site on the Oman Margin which provided a record of the deposition which occurred during the early and middle Miocene. Chalks which contain a relatively high carbonate and foraminiferal content make up the lower and middle Miocene sediments. Calcareous nannofossils Reticulofenestra pseudoumbilica and $R$. gelida occur together in nearly every sample in Zones NN11 through NN15. Backman (1980) has suggested that the presence of both of these forms of Reticulofenestra in the same samples suggests that there was sufficient seasonality to allow the growth of both of these forms. The colder water associated with the annual upwelling is probably responsible for the presence of $R$. gelida in samples from Hole 728A.

Early Miocene nannofossils possess poor preservation which is manifested by heavy overgrowths on sphenoliths, discoasters, and Cyclicargolithus floridanus. Calcareous nannofossil Zones NN4 and NN5 are combined due to the absence of the tropical marker species, Helicosphaera ampliaperta. Planktonic foraminiferal Zones N13 and N14 are combined due to the absence of the marker species which delineates the top of Zone N13. Plank- tonic foraminifers are common to abundant in lower Miocene sediments.

Hiatuses at Sites 726 and 729 prevent the recognition of Oligocene to middle Miocene sediments.

Drilling at Sites 726 and 729 recovered large-foraminifer- to algae-bearing carbonates. The presence of abundant benthic foraminifers including Nummulites cf. planulatus, $N$. cf. pratti, and Actinocyclina sp. provide an Eocene age assignment for this unit. Amphistegid and nummulitid type larger foraminifers suggest that this unit was deposited in shallow water (less than $130 \mathrm{~m})$.

Based on the benthic foraminiferal faunas, it can be deduced that the seafloor at Site 728 has subsided more than $1000 \mathrm{~m}$ since the early Pliocene. The subsidence at Site 724 has been less drastic, probably a deepening on the order of $250 \mathrm{~m}$. Conversely, Site 725 appears to have undergone some uplift during the middle Pleistocene. The shallow-water benthic foraminifer, Ammonia beccarii, is present in only the upper $85 \mathrm{~m}$ of sediment at Hole $725 \mathrm{C}$.

\section{MAGNETOSTRATIGRAPHY}

\section{Quaternary}

When compared to the calcareous nannofossil datums, the Brunhes/Matuyama Chronozone boundary should be observed between 100 and 150 mbsf in Hole 723A. A few reversed samples occur over this interval, but this boundary reversal is not clearly recorded in the sediments at this site. In the lower Pleistocene sediments some reversely magnetized samples exist, but most of the Matuyama Chronozone cannot be recognized. Overall, the Pleistocene sediments at Site 723 are poor recorders of geomagnetic field reversals, and minimal magnetostratigraphic data can be derived from them.

The Brunhes/Matuyama Chronozone boundary and the Jaramillo Subchronozone are tentatively identified at Site 724 . The top of the Olduvai Subchronozone is also recognized.

The remanent magnetization of sediments at Site 725 is low, as at Sites 723 and 724 . Comparison with calcareous nannofossil stratigraphy indicates that the Brunhes/Matuyama Chronozone boundary may be present at 79 mbsf. The Jaramillo Subchronozone is considered to be present between 100 and 121 mbsf at Site 725 .

At Site 726, the base of the Jaramillo Subchronozone is tentatively recognized at $39 \mathrm{mbsf}$.

At Hole $727 \mathrm{~A}$ the inclination data indicates the presence of at least four polarity intervals. The Brunhes Chronozone is present between 0 and $76 \mathrm{mbsf}$. The sediments below $76 \mathrm{mbsf}$ are assigned to the Matuyama Chronozone. The Jaramillo Subchronozone $(\mathrm{C} 1 \mathrm{r}-1)$ is recognized between $95.40-95.83 \mathrm{mbsf}$ and 104.14-104.69 mbsf. The Olduvai Subchronozone (C2) is present between approximately 153.0 and 182.4 mbsf.

A comparatively complete magnetostratigraphic record is present at Site 728 . The Brunhes/Matuyama Chronozone boundary and Jaramillo Subchronozone are recognized. However, the Olduvai Subchronozone appears to be missing.

Because the RCB system was used at Site 729 , no attempt was made to measure the magnetic signal of these sediments.

\section{Neogene}

The bottom of the Olduvai Subchronozone and the Matuyama/Gauss Chronozone boundaries are recognized at Site 724. The Matuyama/Gauss and Gauss/Gilbert Chronozone boundaries, the top of the Kaena, and the base of the Mammoth Subchronozones are recorded at Site 728 .

A reversed interval below 75 mbsf at Site 726 corresponds in time to several reversed and normal intervals. No correlations 
were attempted with the geomagnetic time scale because of this anomalous relationship.

The Cochiti, Nunivak, Sidufjall, and Thvera Subchronozones are recorded in sediments at Site 728 . The interval between 40 and $110 \mathrm{mbsf}$ is characterized by higher intensities than those of the sediments above and below. A long normal interval is present between 50 and 110 mbsf. The upper part of this normally polarized interval may correlate with Chron C5 (Chronozone 11).

\section{CHRONOSTRATIGRAPHY}

The magnetic anomaly time scale of Berggren et al. (1985) was utilized for assigning ages to the polarity reversals recorded in the Leg 117 sediments. These ages were obtained through the correlation of Anomaly 5 with Chron 11. Ages for some calcareous nannofossil and planktonic foraminifer datums have been calculated based on the sediments recovered on this leg. These new ages (Table 1) can be found in Kroon et al. (this volume), Sato et al. (this volume), and Spaulding (this volume). Radiolarian event ages are taken from Johnson and Nigrini (1985) and Johnson et al. (1989).

The top of the acme of the calcareous nannofossil, Reticulofenestra asanoi, occurs within or just below the Brunhes/Matuyama reversal boundary on the Oman Margin. Also on the margin, the LAD of Gephyrocapsa parallela occurs just above the top of the Jaramillo Subchronozone. However, on the Owen Ridge the FAD of $G$. parallela occurs just above the bottom of the Jaramillo Subchronozone. The LAD of large gephyrocapsids occurs just below the Jaramillo Subchronozone on the Owen Ridge and the Oman Margin. However, at another site on the margin, this datum occurs at levels coincident with the bottom of the Jaramillo Subchronozone. Helicosphaera sellii has its LAD between the Jaramillo and Olduvai Subchronozones on the Oman Margin.

Many of the ages of Neogene planktonic foraminiferal events (Kroon et al., this volume) appear to be diachronous. This is consistent with the conclusions reached by Dowsett (1989). Obviously anomalous planktonic foraminiferal ages include those in the Neogloboquadrina-Pulleniatina lineages. The FAD of Globorotalia truncatulinoides, G. tosaensis, and G. crassaformis occur in the Arabian Sea (Kroon et al., this volume) much later than in other regions (Hills and Thierstein, 1989).

As can be seen in Table 3, 4, 5, 11, and 13, the order of radiolarian events is quite consistent in sediments younger than 4.5 Ma. In older sediments, however, the order in which these events occur becomes much more unstable. This is probably due to the fact that the ages younger than $4.5 \mathrm{Ma}$ have been derived paleomagnetically (Johnson et al., 1989) from piston cores.

\section{SEDIMENTATION RATES}

\section{Indus Fan}

The sedimentation rate at Site 720 (Fig. 3) is based solely on calcareous nannofossil datums (Table 2). The uppermost $5 \mathrm{~m}$ show a sedimentation rate of $21 \mathrm{~m} / \mathrm{m}$.y. This corresponds to an interval of nannofossil ooze deposition on the Indus Fan. In the turbiditic sequence the sedimentation rate ranges between 133 and $600 \mathrm{~m} / \mathrm{m} . \mathrm{y}$.

\section{Owen Ridge}

The sedimentation rate curve for Site 721 (Fig. 4) is based on calcareous nannofossils, planktonic foraminifers, radiolarians, and magnetostratigraphy (Table 3 ). The sedimentation rate at this site is rather uniform in the uppermost $247 \mathrm{~m}$, ranging between 25 and $59 \mathrm{~m} / \mathrm{m}$.y. Between 247 and 261 mbsf the sedimentation rate drops to $7 \mathrm{~m} / \mathrm{m}$.y. From $261 \mathrm{mbsf}$ to $320 \mathrm{mbsf}$ the sedimentation rate ranges between 30 and $37 \mathrm{~m} / \mathrm{m}$.y. The basal part of this site (347-424.2 mbsf) consists of turbiditic sequences of clayey siltstones to mudstones. No datums are avail-
Table 1. Ages of polarity reversal boundaries and biostratigraphic events for Leg 117. ( $\mathrm{T}=$ upper limit, $\mathrm{B}=$ lower limit, / = evolutionary transition)."

\begin{tabular}{|c|c|c|c|c|}
\hline & & Event & $\begin{array}{l}\text { Age } \\
(\mathrm{Ma})\end{array}$ & $\begin{array}{l}\text { Source } \\
\text { of age } \mathrm{e}^{\mathrm{a}}\end{array}$ \\
\hline P1 & B & Globorotalia theyeri & $0.12 ; 0.36$ & 1 \\
\hline Ni & $\mathrm{T}$ & Helicosphaera inversa & 0.15 & 2 \\
\hline N2 & B & Emiliania huxleyi & $0.23 ; 0.24$ & $3 ; 2$ \\
\hline R1 & $\mathrm{T}$ & Stylatractus universus & $0.37-0.47$ & 4 \\
\hline R2 & B & Collosphaera tuberosa & $0.40-0.59$ & 4 \\
\hline N3 & $\mathrm{T}$ & Pseudoemiliania lacunosa & $0.38 ; 0.39$ & $3 ; 2$ \\
\hline N4 & B & Helicosphaera inversa & 0.48 & 2 \\
\hline P2 & $\mathbf{T}$ & Globorotalia tosaensis & $0.51 ; 0.64$ & 1 \\
\hline P3 & B & Globorotalia crassaformis & $0.60 ; 0.74$ & 1 \\
\hline R3 & $\mathbf{T}$ & Anthocyrtidium nosicaae & $0.66-0.78$ & 4 \\
\hline R4 & $\mathrm{T}$ & Pterocorys campanula & $0.66-0.78$ & 4 \\
\hline P4 & B & Globigerinella calida & $0.69 ; 0.74$ & 1 \\
\hline P5 & B & Globigerinoides tenellus & $0.69 ; 0.89$ & 1 \\
\hline MI & & Brunhes/Matuyama & 0.73 & 5 \\
\hline R5 & B & Pterocorys hertwigii & $0.76-0.84$ & 4 \\
\hline N5 & $\mathrm{T}$ & Reticulofenestra asanoi & $0.70 ; 0.83$ & $3 ; 2$ \\
\hline N6 & B & Gephyrocapsa parallela & $0.85 ; 0.89$ & $3 ; 2$ \\
\hline M2 & $\mathbf{T}$ & Jaramillo & 0.91 & 5 \\
\hline R6 & $\mathrm{T}$ & Anthocyrtidium angulare & $0.94-1.04$ & 4 \\
\hline M3 & B & Jaramillo & 0.98 & 5 \\
\hline P6 & $\mathrm{T}$ & Neogloboquadrina acostaensis & $1.01 ; 1.10$ & 1 \\
\hline R7 & B & Lamprocyrtis nigriniae & $1.02-1.07$ & 4 \\
\hline N7 & B & Acme Reticulofenestra asanoi & 1.06 & 2 \\
\hline R8 & $\mathrm{T}$ & Lamprocyrtis neoheteroporos & $1.09-1.13$ & 4 \\
\hline P7 & B & Globorotalia tosaensis & $1.10 ; 1.40$ & 1 \\
\hline N8 & $\mathbf{T}$ & Gephyrocapsa (large) & $1.07 ; 1.10$ & $3 ; 2$ \\
\hline N9 & $\mathrm{T}$ & Helicosphaera sellii & $1.19 ; 1.34$ & $2 ; 3$ \\
\hline N10 & B & Gephyrocapsa (large) & 1.36 & 2 \\
\hline R9 & $\mathrm{T}$ & Pterocanium prismatium & $1.52-1.56$ & 4 \\
\hline R10 & B & Anthocyrtidium angulare & $1.52-1.56$ & 4 \\
\hline N11 & $\mathrm{T}$ & Calcidiscus macintyrei & $1.47 ; 1.57$ & $3 ; 2$ \\
\hline $\mathrm{N} 12$ & B & Gephyrocapsa oceanica & $1.53 ; 1.57$ & $3 ; 2$ \\
\hline M4 & $\mathbf{T}$ & Olduvai & 1.66 & 5 \\
\hline $\mathrm{N} 13$ & B & Gephyrocapsa caribbeanica & $1.66 ; 1.80$ & $2 ; 3$ \\
\hline P8 & B & Globorotalia truncatulinoides & $1.64 ; 1.85$ & 1 \\
\hline M5 & B & Olduvai & 1.88 & 5 \\
\hline N14 & $\mathbf{T}$ & Discoaster brouweri & $1.91 ; 2.03$ & $2 ; 3$ \\
\hline N15 & B & acme Gephyrocapsa & 2.13 & 2 \\
\hline P9 & $\mathrm{T}$ & Globigerinoides obliqus & $2.20 ; 2.39$ & 1 \\
\hline N16 & $\mathrm{T}$ & acme Crenalithus doronicoides & 2.25 & 2 \\
\hline N17 & $\mathrm{T}$ & Discoaster pentaradiatus & $2.27 ; 2.31$ & $2 ; 3$ \\
\hline N18 & $\mathrm{T}$ & Discoaster surculus & $2.42 ; 2.49$ & $3 ; 2$ \\
\hline R11 & B & Cycladophora davisiana & $2.42-2.44$ & 4 \\
\hline $\mathrm{R} 12$ & B & Theocorythium trachelium & $2.40-2.50$ & 6 \\
\hline M6 & & Matuyama/Gauss & 2.47 & 5 \\
\hline R13 & B & Lamprocyrtis neoheteroporos & $2.51-2.53$ & 4 \\
\hline P10 & $\mathrm{T}$ & Globoquadrina altispira & $2.57 ; 2.66$ & 1 \\
\hline N19 & $\mathrm{T}$ & Discoaster tamalis & $2.62 ; 2.77$ & $2 ; 3$ \\
\hline $\mathrm{N} 20$ & $\mathrm{~T}$ & Reticulofenestra ampla & 2.62 & 2 \\
\hline P11 & $\mathrm{T}$ & Neogloboquadrina humerosa & $2.66 ; 2.81$ & 1 \\
\hline P12 & B & Neogloboquadrina dutertrei & $2.91 ; 3.30$ & 1 \\
\hline M7 & $\mathrm{T}$ & Kaena & 2.92 & 5 \\
\hline $\mathrm{N} 21$ & $\mathbf{T}$ & lower acme $C$. doronicoides & 2.97 & 2 \\
\hline P13 & $\mathbf{T}$ & Globorotalia limbata & $3.11 ; 3.30$ & 1 \\
\hline P14 & & coiling change Pulleniatina(?) & $3.11 ; 3.69$ & 1 \\
\hline M8 & B & Mammoth & 3.18 & 5 \\
\hline R15 & $T$ & Phormostichoartus fistula & $3.26-3.28$ & 4 \\
\hline R16 & $\mathrm{T}$ & Lychnodictyum audax & $3.33-3.35$ & 4 \\
\hline M9 & & Gauss/Gilbert & 3.40 & 5 \\
\hline P15 & B & Globigerinoides ruber & $3.42 ; 3.65$ & 1 \\
\hline N22 & $\mathrm{T}$ & Sphenolithus abies & 3.44 & 3 \\
\hline P16 & $\mathrm{T}$ & Sphaeroidinellopsis spp. & $3.47 ; 3.57$ & 1 \\
\hline R17 & $\mathrm{T}$ & Phormostichoartus doliolum & $3.53-3.55$ & 4 \\
\hline N23 & $\mathrm{T}$ & Reticulofenestra pseudoumbilica & $3.44 ; 3.56$ & $3 ; 2$ \\
\hline P17 & B & Pulleniatina obliquiloculata & $3.65 ; 3.80$ & 1 \\
\hline R18 & B & Amphirhopalum ypsilon & $3.77-3.79$ & 4 \\
\hline $\mathbf{R} 20$ & B & Spongaster tetras tetras & $3.83-3.85$ & 4 \\
\hline M10 & $\mathrm{T}$ & Cochiti & 3.88 & 5 \\
\hline M11 & B & Cochiti & 3.97 & 5 \\
\hline M12 & $\mathbf{T}$ & Nunivak & 4.10 & 5 \\
\hline P18 & B & Neogloboquadrina nigriniae & $4.18 ; 4.45$ & 1 \\
\hline M13 & B & Nunivak & 4.24 & 5 \\
\hline R25 & & $S$. berminghami $\rightarrow S$. pentas & $4.3-4.4$ & 6 \\
\hline M14 & $\mathrm{T}$ & Sidufjall & 4.40 & 5 \\
\hline M15 & B & Sidufjall & 4.47 & 5 \\
\hline P19 & B & Sphaeroidinella dehiscens & $4.54 ; 4.55$ & 1 \\
\hline M16 & $\mathrm{T}$ & Thvera & 4.57 & 5 \\
\hline
\end{tabular}


Table 1 (continued).

\begin{tabular}{|c|c|c|c|c|}
\hline & & Event & $\begin{array}{l}\text { Age } \\
\text { (Ma) }\end{array}$ & $\begin{array}{l}\text { Source } \\
\text { of age }\end{array}$ \\
\hline R27 & $\mathrm{T}$ & Solenosphaera omnitubus & $4.7-4.8$ & 6 \\
\hline M17 & B & Thvera & 4.77 & 5 \\
\hline $\mathbf{R} 28$ & $\mathrm{~T}$ & Botryostrobus bramletti & $4.9-5.0$ & 6 \\
\hline R39 & $\mathrm{T}$ & Dendrospyris bursa & $5.0-5.1$ & 6 \\
\hline P20 & B & Pulleniatina primalis & $5.18 ; 5.28$ & 1 \\
\hline P21 & B & Neogloboquadrina tegillata & $5.18 ; 5.28$ & 1 \\
\hline P22 & B & Globorotalia tumida tumida & $5.28 ; 5.34$ & 1 \\
\hline R31 & $\mathrm{T}$ & Acrobotrys tritubus & $5.3-5.4$ & 6 \\
\hline M18 & & Gilbert/Chronozone 5 & 5.35 & 5 \\
\hline P23 & B & Globigerinoides sacculifer & $5.43 ; 5.68$ & 1 \\
\hline P24 & & N. acostaensis $\rightarrow$ Pulleniatina & $5.45 ; 5.55$ & 1 \\
\hline P25 & B & Globorotalia margaritae & $5.50 ; 5.68$ & 1 \\
\hline $\mathrm{N} 24$ & $\mathbf{T}$ & Discoaster quinqueramus & 5.6 & 5 \\
\hline P26 & B & Neogloboquadrina humerosa & $5.55 ; 5.67$ & 1 \\
\hline $\mathrm{N} 25$ & $\mathbf{T}$ & Discoaster berggrenii & 5.6 & 5 \\
\hline R33 & $\mathbf{T}$ & Stichocorys johnsonii & $5.7-5.8$ & 6 \\
\hline M19 & & Chronozone $5 / 6$ & 5.89 & 5 \\
\hline P27 & B & Globorotalia plesiotumida & $5.98 ; 5.99$ & 1 \\
\hline R35 & & $S$. delmontensis $\rightarrow S$. peregrina & $6.1-6.7$ & 6 \\
\hline R37 & $\mathrm{T}$ & Calocycletta caepa & $6.2-6.6$ & 6 \\
\hline R40 & B & Solenosphaera omnitubus & $6.3-6.5$ & 6 \\
\hline R42 & $\mathrm{T}$ & Diartus hughesi & $7.1-7.2$ & 6 \\
\hline R43 & B & Acrobotrys tritubus & $7.7-7.8$ & 6 \\
\hline R47 & B & Spongaster berminghami & $7.9-8.0$ & 6 \\
\hline R48 & $T$ & Stichocorys wolfii & $8.0-8.2$ & 6 \\
\hline R49 & $\mathbf{T}$ & Botryostrobus miralestensis & $8.1-8.2$ & 6 \\
\hline RSO & $\mathrm{T}$ & Diartus petterssoni & $8.1-8.2$ & 6 \\
\hline N26 & B & Discoaster quinqueramus & 8.2 & 5 \\
\hline R51 & & D. petterssoni $\rightarrow D$. hughesi & $8.3-8.5$ & 6 \\
\hline R52 & B & Diartus hughesi & $8.7-8.8$ & 6 \\
\hline R53 & B & Botryostrobus bramletti & $8.8-9.0$ & 6 \\
\hline N28 & $\mathrm{T}$ & Discoaster hamatus & 8.85 & 5 \\
\hline N29 & $\mathrm{T}$ & Catinaster coalitus & 9.0 & 5 \\
\hline N30 & B & Discoaster hamatus & 10.0 & 5 \\
\hline R55 & $\mathrm{T}$ & Cyrtocapsella japonica & $10.0-10.3$ & 6 \\
\hline P28 & $\mathbf{T}$ & Globorotalia mayeri & 10.4 & 5 \\
\hline R56 & B & Diartus petterssoni & $10.6-10.8$ & 6 \\
\hline N31 & B & Catinaster coalitus & 10.8 & 5 \\
\hline P29 & B & Globigerina nepenthes & 11.3 & 5 \\
\hline P30 & $\mathrm{T}$ & Globorotalia fohsi & 11.5 & 5 \\
\hline R57 & B & Phormostichoartus doliolum & $11.1-11.9$ & 6 \\
\hline N33 & $\mathrm{T}$ & Cyclicargolithus floridanus & 11.6 & 6 \\
\hline R59 & $\mathbf{T}$ & Cyrtocapsella cornuta & $11.6-11.9$ & 6 \\
\hline R60 & $\mathrm{T}$ & Lithopera renzae & $12.1-12.3$ & 6 \\
\hline N32 & B & Discoaster kugleri & 13.1 & 5 \\
\hline N34 & $\mathrm{T}$ & Sphenolithus heteromorphus & 14.4 & 5 \\
\hline P31 & $\mathrm{T}$ & Globorotalia peripheronda & 14.6 & 5 \\
\hline P32 & B & Orbulina universa & 15.2 & 5 \\
\hline N35 & $\mathrm{T}$ & Sphenolithus belemnos & 17.1 & 5 \\
\hline
\end{tabular}

${ }^{\text {a }}$ Sources of ages are as follows: $1=$ Kroon et al. (this volume); 2 = Sato et al. (this volume); $3=$ Spaulding (this volume); $4=$ Johnson and Nigrini (1985); $5=$ Berggren et al. (1985); $6=$ Johnson et al. (1989).

able for this part of the sequence, and therefore, no accumulation rate can be calculated.

The sedimentation rate curve for Site 722 (Fig. 5) is based on calcareous nannofossils, planktonic foraminifers, radiolarians, and magnetostratigraphy (Table 4). The sedimentation rate at this site, like Site 721 , is rather consistent, ranging from 23 to 51 $\mathrm{m} / \mathrm{m}$.y. A relatively uniform sedimentation rate is not unexpected for the accumulation of pelagic nannofossil oozes and chalks. The lower sequence of sediments at this site (411.1$565.6 \mathrm{mbsf}$ ) consists of interbedded fine-grained turbidites and marly nannofossil chalks. Because no stratigraphic datums are recognized within this interval, it is not included in Figure 5.

The sedimentation rate curve for Site 731 (Fig. 6) is based on calcareous nannofossils, planktonic foraminifers, radiolarians, and magnetostratigraphy (Table 5). The sedimentation rate at this site on the Owen Ridge has fluctuated since the early Miocene. The accumulation rate ranges from 18 to $49 \mathrm{~m} / \mathrm{m}$.y. A hiatus, of up to $2 \mathrm{~m} . \mathrm{y}$. in duration, is present at approximately

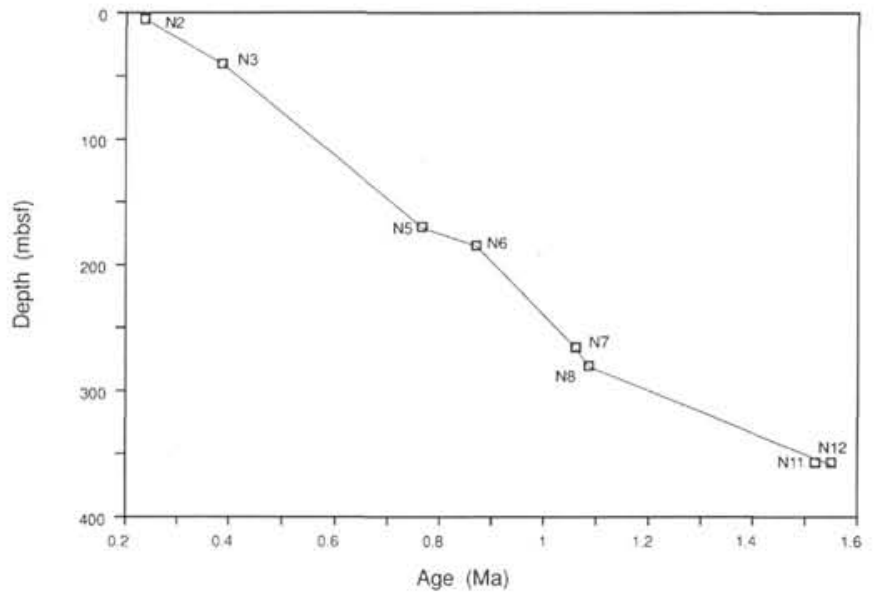

Figure 3. Sedimentation rate curve for Site 720 .

Table 2. Biostratigraphic events at Site 720.

\begin{tabular}{ccc}
\hline \multicolumn{1}{c}{ Event } & $\begin{array}{c}\text { Hole 720A depth } \\
\text { (mbsf) }\end{array}$ \\
\hline Calcareous nannofossils \\
N2 & B Emiliania huxleyi & $4.00-6.00$ \\
N3 & T Pseudoemiliania lacunosa & $38.20-42.64$ \\
N5 & T Reticulofenestra asanoi & $164.00-175.53$ \\
N6 & B Gephyrocapsa parallela & $183.40-185.60$ \\
N7 & B acme Reticulofenestra asanoi & $260.50-270.10$ \\
N8 & T Gephyrocapsa (large) & $279.80-280.80$ \\
N11 & T Calcidiscus macintyrei & $347.14-366.24$ \\
N12 & B Gephyrocapsa oceanica & $347.14-366.24$ \\
\hline
\end{tabular}

100 mbsf. The Pleistocene sedimentation rate is comparable, but a bit higher than the rates at Sites 721 and 722 .

\section{Oman Margin}

The sedimentation rate curve for Site 723 (Fig. 7) is based primarily on calcareous nannofossils with one planktonic foraminiferal datum (Table 6). The accumulation rate ranges between 122 and $194 \mathrm{~m} / \mathrm{m}$.y. This site accumulated sediments a rate faster than any of the other sites of this leg, with the exception of the Indus Fan site (720). These rates which are typical of hemipelagic sedimentation are, on the average, about five times higher than the rate of pelagic accumulation at the Owen Ridge sites.

The sedimentation rate curve for Site 724 (Fig. 8) is based primarily on calcareous nannofossils (Table 7). The rates of accumulation range between 75 and $94 \mathrm{~m} / \mathrm{m}$.y. for the uppermost $192.55 \mathrm{~m}$ of sediment. From 192.55 to $240 \mathrm{mbsf}$ the rate is lower, approximately $40 \mathrm{~m} / \mathrm{m}$.y. The sedimentation rate at this site is about one-half that of Site 723. This is probably due to the fact that Site 723 is located in the center of a large slope basin while this site is located in the center of a smaller and shallower slope basin.

The sedimentation rate curve for Site 725 (Fig. 9) is based solely on calcareous nannofossil datums (Table 8). The sedimentation rate ranges from 98 to $160 \mathrm{~m} / \mathrm{m}$.y. Between 100 and 103 mbsf, the sedimentation rate is only $29 \mathrm{~m} / \mathrm{m}$.y.; it is possible that a hiatus is present within this interval.

The sedimentation rate curve for Site 726 (Fig. 10) is based on calcareous nannofossils and planktonic foraminifers (Table 9). The sedimentation rate for the upper $71 \mathrm{~m}$ of sediment ranges from 28 to $63 \mathrm{~m} / \mathrm{m}$.y. This higher sedimentation rate is for silty clays and calcareous oozes with varying amounts of foraminifers. In the lower half of Hole 726A (71-118 mbsf) the sedimen- 


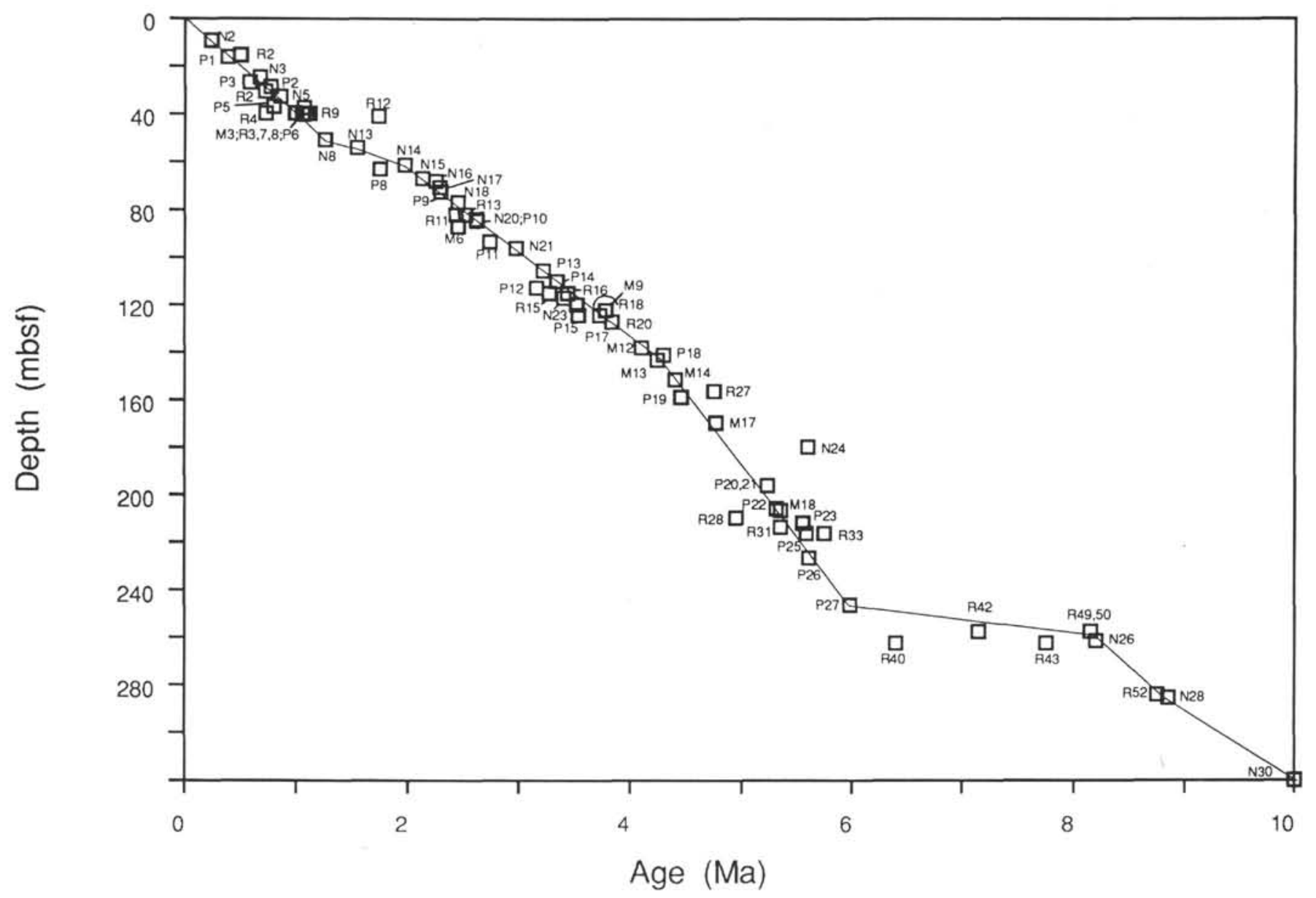

Figure 4. Sedimentation rate curve for Site 721.

tation rate is much lower, about $4-9 \mathrm{~m} / \mathrm{m}$.y. This much lower accumulation rate is for lithologies which contain lag deposits of foraminifers, fish teeth, and fish bones which are interbedded with $\mathrm{C}_{\text {org }}$-rich nannofossil-foraminifer oozes. This lower rate of sedimentation is not unexpected for sediments which possess features that are diagnostic of non-deposition and winnowing.

The sedimentation rate curve for Site 727 (Fig. 11) is based on calcareous nannofossils, planktonic foraminifers, and magnetostratigraphy (Table 10). The accumulation rates range from 53 to $130 \mathrm{~m} / \mathrm{m}$.y. Site 723 , located nearby, accumulated sediments at a rate two times that of this site, which is located near the edge of the same basin.

The sedimentation rate curve for Site 728 (Fig. 12) is based on calcareous nannofossils, planktonic foraminifers, radiolarians, and magnetostratigraphy (Table 11). The accumulation rate for the last $3.56 \mathrm{~m}$.y. ranges between 13 and $52 \mathrm{~m} / \mathrm{m}$.y. A higher sedimentation rate $(84 \mathrm{~m} / \mathrm{m}$.y.) existed between 3.56 and 5.75 Ma. This higher sedimentation rate during the late Miocene and early Pliocene and the concomitant deposition of sediments with accumulations of $\mathrm{C}_{\mathrm{org}}$ and siliceous microfossils may be the result of increased primary productivity during this time. The sedimentation rate between 5.75 and 8.15 Ma ranged from 18 to 48 $\mathrm{m} / \mathrm{m}$.y. This site, which is located in a lower slope basin, accumulates sediments of a more strictly pelagic nature than the other sites on the Oman Margin. This accounts for its lower overall sedimentation rate.

The sedimentation rate curve for Site 729 (Fig. 13) is based solely on calcareous nannofossil datums (Table 12). The curve represents the sedimentation rate of Lithologic Unit I (nanno- fossil-foraminifer-rich mud to marly nannofossil ooze) only. The sedimentation rate at this site ranges from 8 to $48 \mathrm{~m} / \mathrm{m}$.y. The lower hemipelagic sedimentation rate is probably due to the effects of winnowing. Evidence for this are silty foraminiferal sand layers which range from 0.2 to $1.5 \mathrm{~m}$ in thickness.

The sedimentation rate curve for Site 730 (Fig. 14) is based on calcareous nannofossils, planktonic foraminifers, and radiolarians (Table 13). The upper Pleistocene sediments at this site were deposited at a rate of $15 \mathrm{~m} / \mathrm{m}$.y. A hiatus is present at approximately $14 \mathrm{mbsf}$ which separates the Pleistocene and upper Miocene sediments. The Miocene units have sedimentation rates which range between 22 and $45 \mathrm{~m} / \mathrm{m}$.y. These rates are similar to those calculated for pelagic sedimentation on the Owen Ridge.

\section{SUMMARY AND CONCLUSIONS}

Very limited data are available regarding calcareous nannofossils in upwelling regions. However, an examination of the species lists of taxa from upwelling regions in the Arabian Sea (DSDP Leg 23) and the Gulf of Aden (DSDP Leg 24) indicates that ceratoliths, amauroliths, and discoasters are less abundant in sediments deposited in upwelling regions. Conversely, Coccolithus pelagicus is a more dominant component of the same assemblages. Cold water related to upwelling along the western edge of the Arabian Sea most likely accounts for the general scarcity of ceratoliths and amauroliths in sediments from Sites 720 through 731 . The abundance of Coccolithus pelagicus in the upper Pliocene to lower Pleistocene sediments at Sites 723, $724,726,727$, and 728 may be explained by the occurrences of glaciations between 2.5 and 1.8 m.y. ago, which were at least 
Table 3. Biostratigraphic and paleomagnetic events at Site 721.

\begin{tabular}{|c|c|c|c|c|}
\hline & & Event & $\begin{array}{c}\text { Hole 721A depth } \\
\text { (mbsf) }\end{array}$ & $\begin{array}{l}\text { Hole 721B depth } \\
\text { (mbsf) }\end{array}$ \\
\hline \multicolumn{5}{|c|}{ Calcareous nannofossils } \\
\hline N2 & B & Emiliania huxleyi & $8.65-9.80$ & \\
\hline N3 & $T$ & Pseudoemiliania lacunosa & $15.45-16.95$ & \\
\hline N5 & $T$ & Reticulofenestra asanoi & $28.12-29.20$ & \\
\hline N6 & B & Gephyrocapsa parallela & $31.85-33.35$ & \\
\hline N7 & B & acme Reticulofenestra asanoi & $36.54-38.04$ & \\
\hline N8 & $\mathrm{T}$ & Gephyrocapsa (large) & $38.90-40.05$ & \\
\hline N13 & B & Gephyrocapsa caribbeanica & $40.05-41.55$ & \\
\hline N14 & $\mathbf{T}$ & Discoaster brouweri & $60.45-61.95$ & \\
\hline N15 & B & acme Gephyrocapsa & $66.45-67.33$ & \\
\hline N16 & $\mathbf{T}$ & acme Crenalithus doronicoides & $67.33-68.45$ & \\
\hline N17 & $\mathbf{T}$ & Discoaster pentaradiatus & $69.95-71.45$ & \\
\hline N18 & $\mathbf{T}$ & Discoaster surculus & $74.45-79.45$ & \\
\hline N20 & $T$ & Reticulofenestra ampla & $83.95-85.45$ & \\
\hline N21 & $T$ & lower acme Crenalithus doronicoides & & $95.60-96.75$ \\
\hline N23 & $\mathrm{T}$ & Reticulofenestra pseudoumbilica & & $114.80-115.95$ \\
\hline N24 & $T$ & Discoaster quinqueramus & & $178.85-180.05$ \\
\hline N26 & B & Discoaster quinqueramus & & $260.65-262.17$ \\
\hline N28 & $T$ & Discoaster hamatus & & $281.53-289.00$ \\
\hline N30 & B & Discoaster hamatus & & $319.15-320.65$ \\
\hline
\end{tabular}

Planktonic foraminifers

$\begin{array}{llll}\text { P1 } & \text { B Globorotalia theyeri } & 14.96 \\ \text { P3 } & \text { B Globorotalia crassaformis } & 24.66 \\ \text { P2 } & \text { T Globorotalia tosaensis } & 26.62 \\ \text { P4 } & \text { B Globigerinella calida } & 30.47 \\ \text { P5 } & \text { B Globigerinoides tenellus } & 36.81 \\ \text { P6 } & \text { T Neogloboquadrina acostaensis } & 40.16 \\ \text { P7 } & \text { B Globorotalia tosaensis } & 50.66 \\ \text { P8 } & \text { B Globorotalia truncatulinoides } & 62.96 \\ \text { P9 } & \text { T Globigerinoides obliquus } & 72.46 \\ \text { P10 } & \text { T Globoquadrina altispira } & 83.91\end{array}$

93.44
105.50
105.50
112.93
119.96
124.47
124.47
140.96
158.66
195.89
195.89
205.66
206.85
216.04
219.37
226.55
246.30

Radiolarians

$\begin{array}{lll}\text { R2 } & \text { B } & \text { Collosphaera tuberosa } \\ \text { R1 } & \text { T } & \text { Stylatractus universus } \\ \text { R3 } & \text { T } & \text { Anthocyrtidium nosicaae } \\ \text { R4 } & \text { T } & \text { Pterocorys campanula } \\ \text { R6 } & \text { T } & \text { Anthocyrtidium angulare } \\ \text { R7 } & \text { B } & \text { Lamprocyrtis nigriniae } \\ \text { R8 } & \text { T } & \text { Lamprocyrtis neoheteroporos } \\ \text { R9 } & \text { T } & \text { Pterocanium prismatium } \\ \text { R10 } & \text { B } & \text { Anthocyrtidium angulare } \\ \text { R12 } & \text { B } & \text { Theocorythium trachelium } \\ \text { R11 } & \text { B } & \text { Cycladophora davisiana } \\ \text { R13 } & \text { B } & \text { Lamprocyrtis neoheteroporos } \\ \text { R14 } & \text { T } & \text { Stichocorys peregrina } \\ \text { R15 } & \text { T } & \text { Phormostichoartus fistula } \\ \text { R16 } & \text { T } & \text { Lychnodictyum audax } \\ \text { R17 } & \text { T } & \text { Phomostichoartus doliolum } \\ \text { R18 } & \text { B } & \text { Amphirhopalum ypsilon } \\ \text { R19 } & \text { T } & \text { Spongodiscus ambus } \\ \text { R20 } & \text { B } & \text { Spongaster tetras tetras } \\ \text { R26 } & \text { T } & \text { Didymocyrtis penultima } \\ \text { R23 } & \text { T } & \text { Dictyophimus splendens } \\ \text { R27 } & \text { T } \text { Solenosphaera omnitubus } \\ \text { R30 } & \text { T Stichocorys delmontensis } \\ \text { R29 } & \text { T Siphostichartus corona } \\ & & \end{array}$

12.55-17.90

22.25-31.95

37.30-41.65

$37.30-41.65$

$37.30-41.65$

$37.30-41.65$

$37.30-41.65$

$51.25-56.60$

$51.25-56.60$

$51.25-56.60$

$79.55-84.90$

79.55-84.90

84.90-89.15

$105.20-114.80$

$105.20-114.80$

$120.15-124.40$

$120.15-124.40$

$120.15-124.40$

$124.40-129.75$

$129.75-134.10$

$153.50-158.85$

153.50-158.85

163.20-168.55

202.22-207.35 


\section{S. A. SPAULDING ET AL.}

Table 3 (continued).

\begin{tabular}{|c|c|c|c|c|}
\hline \multicolumn{3}{|r|}{ Event } & $\begin{array}{l}\text { Hole 721A depth } \\
\text { (mbsf) }\end{array}$ & $\begin{array}{c}\text { Hole 721B depth } \\
\text { (mbsf) }\end{array}$ \\
\hline \multicolumn{5}{|c|}{ Radiolarians (cont.) } \\
\hline R28 & $\mathrm{T}$ & Botryostrobus bramlettei & & $207.35-211.70$ \\
\hline R31 & $\mathbf{T}$ & Acrobotrys tritubus & & $211.70-215.55$ \\
\hline R33 & $\mathrm{T}$ & Stichocorys johnsoni & & $215.55-216.79$ \\
\hline R34 & $\mathrm{T}$ & Didymocyrtis antepenultima & & $225.15-226.56$ \\
\hline R35 & & $S$. delmontensis $\rightarrow S$. peregrina & & $226.56-235.85$ \\
\hline R36 & B & Spondiscus ambus & & $240.10-245.45$ \\
\hline R42 & $T$ & Diartus hughesi & & $255.15-259.60$ \\
\hline R49 & $\mathrm{T}$ & Botryostrobus miralestensis & & $255.15-259.60$ \\
\hline R50 & B & Diartus petterssoni & & $255.15-259.60$ \\
\hline R39 & $\mathrm{T}$ & Dendrospyris bursa & & $259.60-264.95$ \\
\hline R40 & B & Solenosphaera omnitubus & & $259.60-264.95$ \\
\hline R41 & B & Stichocorys peregrina & & $259.60-264.95$ \\
\hline R43 & B & Acrobotrys tritubus & & $259.60-264.95$ \\
\hline R46 & $\mathrm{T}$ & Didymocyrtis laticonus & & $264.95-269.40$ \\
\hline R52 & B & Diartus hughesi & & $279.20-289.00$ \\
\hline \multicolumn{5}{|c|}{ Polarity reversals } \\
\hline M3 & B & Jaramillo & $38.55-40.05$ & \\
\hline M6 & & Matuyama/Gauss & $79.76-80.15$ & $85.05-86.35$ \\
\hline M9 & & Gauss/Gilbert & & $116.65-117.45$ \\
\hline M12 & $\mathrm{T}$ & Nunivak(?) & & $137.45-138.25$ \\
\hline M13 & B & Nunivak(?) & & $141.95-144.14$ \\
\hline M14 & $\mathrm{T}$ & Sidufjall & & $150.95-151.66$ \\
\hline M17 & B & Thvera & & $167.35-171.85$ \\
\hline M18 & & Gilbert/5 & & $206.15-106.85$ \\
\hline
\end{tabular}

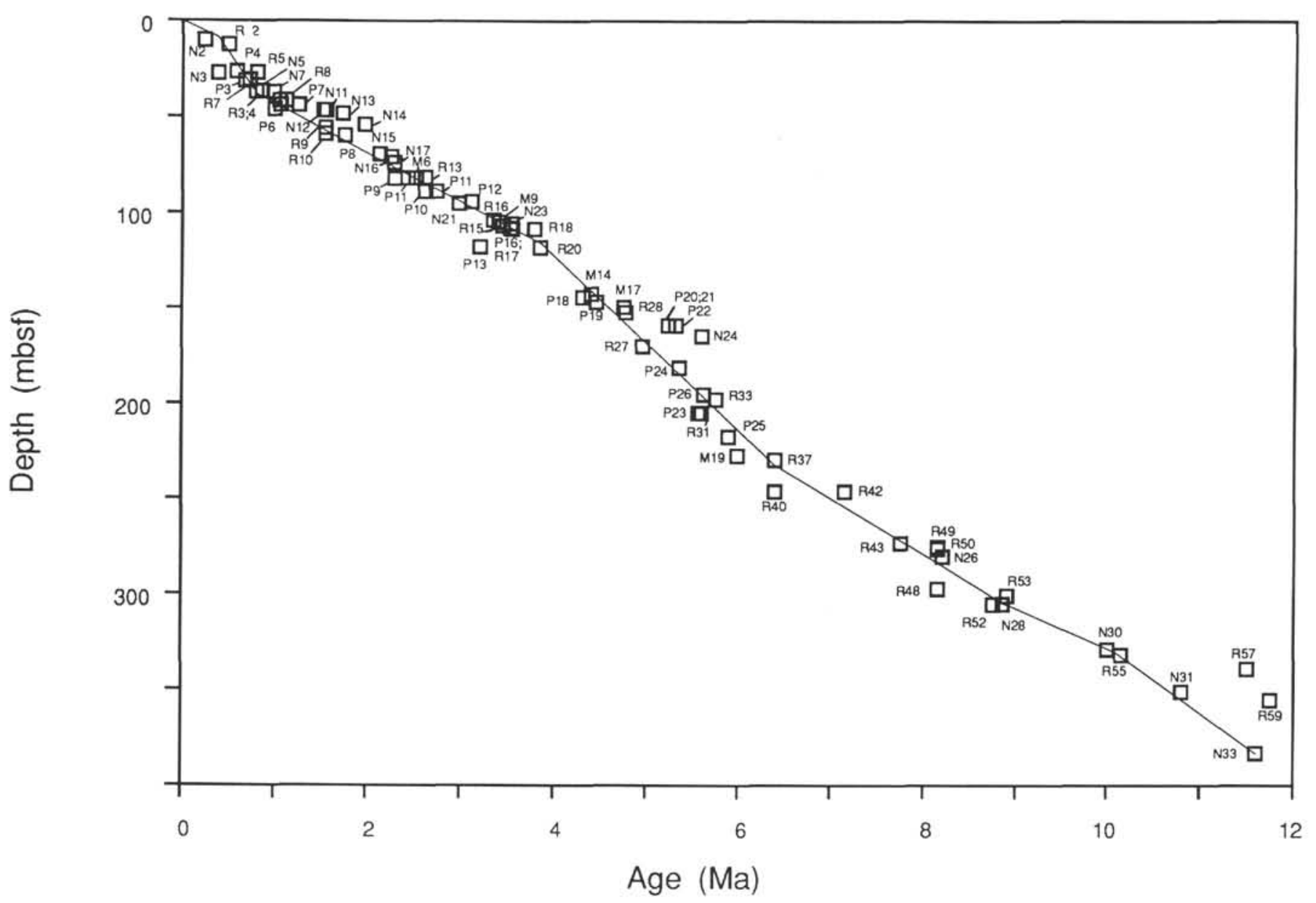

Figure 5. Sedimentation rate curve for Site 722. 
Table 4. Biostratigraphic and paleomagnetic events at Site 722.

\begin{tabular}{|c|c|c|c|c|}
\hline \multicolumn{3}{|r|}{ Event } & $\begin{array}{l}\text { Hole } 722 \mathrm{~A} \text { depth } \\
\text { (mbsf) }\end{array}$ & $\begin{array}{c}\text { Hole 722B depth } \\
\text { (mbsf) }\end{array}$ \\
\hline \multicolumn{5}{|c|}{ Calcareous nannofossils } \\
\hline N2 & B & Emiliania huxleyi & $9.80-10.95$ & \\
\hline N3 & $\mathrm{T}$ & Pseudoemiliania lacunosa & $26.55-27.70$ & \\
\hline N5 & $\mathrm{T}$ & Reticulofenestra asanoi & $31.68-33.15$ & \\
\hline N6 & B & Gephyrocapsa parallela & $36.15-37.30$ & \\
\hline N7 & B & acme Reticulofenestra asanoi & $39.75-41.25$ & \\
\hline N8 & $\mathrm{T}$ & Gephyrocapsa (large) & $42.75-44.25$ & \\
\hline N11 & $\mathrm{T}$ & Calcidiscus macintyrei & $45.75-47.25$ & \\
\hline $\mathrm{N} 12$ & B & Gephyrocapsa oceanica & $45.75-47.25$ & \\
\hline N13 & B & Gephyrocapsa caribbeanica & $47.25-48.75$ & \\
\hline N14 & $\mathrm{T}$ & Discoaster brouweri & $53.14-54.66$ & \\
\hline N15 & B & acme Gephyrocapsa & $68.35-69.85$ & \\
\hline N16 & $\mathbf{T}$ & acme Crenalithus doronicoides & $69.85-71.35$ & \\
\hline N17 & $\mathrm{T}$ & Discoaster pentaradiatus & $72.84-74.35$ & \\
\hline $\mathrm{N} 20$ & $\mathrm{~T}$ & Reticulofenestra ampla & $80.83-81.95$ & \\
\hline N21 & $\mathbf{T}$ & lower acme Crenalithus doronicoides & $93.73-96.20$ & \\
\hline N23 & $\mathrm{T}$ & Reticulofenestra pseudoumbilica & $105.90-107.06$ & \\
\hline N24 & $\mathbf{T}$ & Discoaster quinqueramus & $163.90-165.05$ & \\
\hline N26 & B & Discoaster quinqueramus & & $275.60-285.30$ \\
\hline N28 & $\mathrm{T}$ & Discoaster hamatus & & $304.70-305.85$ \\
\hline N30 & B & Discoaster hamatus & & $324.00-333.70$ \\
\hline N31 & B & Catinaster coalitus & & $349.05-353.10$ \\
\hline N32 & B & Discoaster kugleri & & $375.10-382.20$ \\
\hline N33 & $\mathbf{T}$ & Cyclicargolithus floridanus & & $382.20-384.02$ \\
\hline N35 & $\mathbf{T}$ & Sphenolithus belemnos & & $433.15-552.28$ \\
\hline
\end{tabular}

Planktonic foraminifers

$\begin{array}{lllr}\text { P1 } & \text { B } \text { Globorotalia theyeri } & 5.16 \\ \text { P2 } & \text { B Globorotalia tosaensis } & 21.56 \\ \text { P4 } & \text { B Globigerinella calida } & 29.01 \\ \text { P5 } & \text { B Globigerinoides tenellus } & 29.01 \\ \text { P3 } & \text { B Globorotalia crassaformis } & 31.16 \\ \text { P6 } & \text { T Neogloboquadrina acostaensis } & 43.76 \\ \text { P7 } & \text { B Globorotalia tosaensis } & 43.76 \\ \text { P8 } & \text { B Globorotalia truncatulinoides } & 59.66 \\ \text { P9 } & \text { T Globigerinoides obliqus } & 81.96 \\ \text { P10 } & \text { T Globoquadrina altispira } & 88.66 \\ \text { P11 } & \text { T Neogloboquadrina humerosa } & 88.66 \\ \text { P12 } & \text { B Neogloboquadrina dutertrei } & 94.18 \\ \text { P15 } & \text { B Globigerinoides ruber } & 105.66 \\ \text { P16 } & \text { T Sphaeroidinellopsis spp. } & 108.06 \\ \text { P14 } & & \text { coiling change Pulleniatina(?) } & 111.05 \\ \text { P13 } & \text { T Globorotalia limbata } & 117.76 \\ \text { P17 } & \text { B Pulleniatina obliquiloculata } & 120.76 \\ \text { P18 } & \text { B Neogloboquadrina nigriniae } & 144.33 \\ \text { P19 } & \text { B Sphaeroidinella dehiscens } & 146.73 \\ \text { P20 } & \text { B Pulleniatina primalis } & 158.80 \\ \text { P21 } & \text { B Neogloboquadrina tegillata } & 158.80 \\ \text { P22 } & \text { B Globorotalia tumida tumida } & 158.80 \\ \text { P24 } & & \text { N. acostaensis } \rightarrow \text { Pulleniatina } & 188.46 \\ \text { P26 } & \text { B Neogloboquadrina humerosa } & 195.16 \\ \text { P23 } & \text { B Globigerinoides sacculifer } & 204.86 \\ \text { P25 } & \text { B Globorotalia margaritae } & 227.16\end{array}$

Radiolarians

$\begin{array}{lllr}\text { R2 } & \text { B Collosphaera tuberosa } & \\ \text { R5 } & \text { B Pterocorys hertwigii } & 2.80-15.15 \\ \text { R7 } & \text { B Lamprocyrtis nigriniae } & 38.60-43.95 \\ \text { R8 } & \text { T Lamprocyrtis neoheteroporos } & 38.60-43.95 \\ \text { R3 } & \text { T Anthocyrtidium nosicace } & 43.95-48.20 \\ \text { R4 } & \text { T Pterocorys campanula } & 43.95-48.20 \\ \text { R6 } & \text { T Anthocyrtidium angulare } & 43.95-48.20 \\ \text { R12 } & \text { B Theocorythium trachelium } & 48.20-50.55 \\ \text { R9 } & \text { T Pterocanium prismatium } & 53.55-57.50 \\ \text { R10. } & \text { B Anthocyrtidium angulare } & 57.50-59.85 \\ \text { R11 } & \text { B Cycladophora davisiana } & 76.80-86.50 \\ \text { R13 } & \text { B Lamprocyrtis neoheteroporos } & 76.80-86.50 \\ \text { R14 } & \text { T Stichocorys peregrina } & 76.80-86.50 \\ \text { R15 } & \text { T Phormostichoartus fistula } & 101.55-105.90 \\ \text { R16 } & \text { T Lychnodictyum audax } & 101.55-105.90 \\ \text { R17 } & \text { T Phormostichoartus doliolum } & 105.90-111.25 \\ \text { R18 } & \text { B Amphirhopalum ypsilon } & 105.90-111.25 \\ \text { R20 } & \text { B Spongaster tetras tetras } & 115.60-120.95 \\ \text { R25 } & & \text { S. berminghami } \rightarrow \text { S. pentas } & 115.60-120.95 \\ \text { R23 } & \text { T Dictyophimus splendens } & 125.30-130.65 \\ \text { R24 } & \text { T Spongodiscus ambus } & 130.65-134.90 \\ \text { R26 } & \text { T Didymocyrtis penultima } & 134.90-140.25\end{array}$


Table 4 (continued).

\begin{tabular}{|c|c|c|c|c|}
\hline & & Event & $\begin{array}{c}\text { Hole } 722 \mathrm{~A} \text { depth } \\
\text { (mbsf) }\end{array}$ & $\begin{array}{c}\text { Hole 722B depth } \\
\text { (mbsf) }\end{array}$ \\
\hline \multicolumn{5}{|c|}{ Radiolarians (cont.) } \\
\hline R27 & $\mathbf{T}$ & Solenosphaera omnitubus & $144.60-154.30$ & \\
\hline R28 & $\mathbf{T}$ & Botryostrobus bramletti & $166.25-173.60$ & \\
\hline R29 & $\mathbf{T}$ & Siphostichoartus corona & $178.95-183.30$ & \\
\hline R30 & $\mathrm{T}$ & Stichocorys delmontensis & $183.30-188.65$ & \\
\hline R33 & $\mathrm{T}$ & Stichocorys johnsonii & $193.00-202.70$ & \\
\hline R31 & $\mathrm{T}$ & Acrobotrys tritubus & $208.05-212.40$ & \\
\hline R36 & B & Spondiscus ambus & $208.05-212.40$ & \\
\hline R35 & & $S$. delmontensis $\rightarrow S$. peregrina & $212.40-217.75$ & \\
\hline R37 & $\mathbf{T}$ & Calocycletta caepa & $227.35-231.70$ & \\
\hline R38 & $\mathrm{T}$ & Phormostichoartus marylandicus & $231.70-241.70$ & \\
\hline R39 & $\mathrm{T}$ & Dendrospyris bursa & $231.70-241.70$ & \\
\hline R40 & B & Solenosphaera omnitubus & $241.70-251.00$ & \\
\hline R41 & B & Stichocorys peregrina & $241.70-251.00$ & \\
\hline R42 & $\mathrm{T}$ & Diartus hughesi & $241.70-251.00$ & \\
\hline R34 & $\mathrm{T}$ & Didymocyrtis antepenultima & $256.30-260.70$ & \\
\hline R45 & $\mathrm{T}$ & Dictyocoryne ontongensis & $270.40-280.00$ & \\
\hline R46 & $\mathbf{T}$ & Didymocyrtis laticonus & $270.40-280.00$ & \\
\hline R49 & $\mathrm{T}$ & Botryostrobus miralestensis & $270.40-280.00$ & \\
\hline R43 & B & Acrobotrys tritubus & & $271.25-275.16$ \\
\hline R50 & $\mathrm{T}$ & Diartus petterssoni & & $275.16-277.71$ \\
\hline R51 & & D. petterssoni $\rightarrow$ D.hughesi & & $277.71-301.50$ \\
\hline R48 & $\mathrm{T}$ & Stichocorys wolfii & & $294.36-300.35$ \\
\hline R53 & B & Botryostrobus bramletti & & $300.35-301.50$ \\
\hline R47 & B & Spongaster berminghami & & $301.50-309.29$ \\
\hline R52 & B & Diartus hughesi & & $301.50-309.29$ \\
\hline R54 & B & Dictyocoryne ontongensis & & $301.50-309.29$ \\
\hline R55 & $T$ & Cyrtocapsella japonica & & $329.35-333.80$ \\
\hline R57 & B & Phormostichoartus doliolum & & $339.05-339.31$ \\
\hline R58 & $\mathrm{T}$ & Lithopera thornburgi & & $348.75-352.93$ \\
\hline R59 & $T$ & Cyrtocapsella cornuta & & $352.75-352.93$ \\
\hline \multicolumn{5}{|c|}{ Polarity reversals } \\
\hline M3 & B & Jaramillo & $37.65-38.40$ & $39.80-40.60$ \\
\hline M6 & & Matuyama/Gauss & $82.45-83.25$ & $83.80-85.20$ \\
\hline M9 & & Gauss/Gilbert & $103.95-105.35$ & $104.00-105.58$ \\
\hline M14 & $\mathbf{T}$ & Sidufjall & $142.05-142.85$ & \\
\hline M17 & B & Thvera & $151.00-153.30$ & $152.40-155.40$ \\
\hline M18 & & Gilbert/Chronozone 5 & $180.73-181.55$ & $181.39-189.60$ \\
\hline M19 & & Chronozone $5 / 6$ & $214.34-220.37$ & $218.50-221.50$ \\
\hline
\end{tabular}

two-thirds the magnitude of late Pleistocene glacial maxima (Shackleton and Opdyke, 1977). According to Perch-Nielsen (1985), the genus Helicosphaera seems to be more abundant in hemipelagic sediments and may prefer areas of upwelling. This may account for the large numbers of this genus found in the Pliocene and Pleistocene sediments at some of the sites (723, 724,725 , and 728).

A graph of the species diversity of the calcareous nannofossils for Leg 117 when compared to a typical tropical region (Shipboard Scientific Party, 1989, p. 603) shows that the nannofloras in the Arabian Sea may have first been affected by the upwelling waters during the early late Miocene (approximately 9.5 Ma).

An examination of the living planktonic foraminifers present in the surface waters of the Arabian and Red Seas during the summer of 1984 and 1985 (Kroon, 1988; Auras-Schudnagies et al., in press) indicates that the "upwelling assemblages" are dominated by Globigerina bulloides and Neogloboquadrina dutertrei. Other species present in lesser quantities include Globorotalia menardii and Pulleniatina obliquiloculata.

The presence of the cold-water benthic foraminifer, Hyalinea balthica, in the Pliocene and Pleistocene sediments of Sites 723 and 724 may be correlative with the increased numbers of the nannofossil, Coccolithus pelagicus, at the same time intervals at the same sites. The above discussion about the late Pliocene to early Pleistocene glaciations may well be applicable to the presence of $H$. balthica in the sediments as well. It cannot be determined to what extent the combination of the glaciation with the upwelling in the Arabian Sea may have affected the presence of cold-water taxa.

The comparison of the radiolarian assemblages from the Peru Margin (ODP Leg 112) with those from this leg indicate that a specific assemblage may be unique to upwelling areas. Three categories of radiolarians can be recognized in upwelling assemblages. These are:

1. Taxa endemic to upwelling,

2. Taxa abundant in middle latitudes, but also present in areas of upwelling, and

3. Tropical taxa which are more robust and/or more abundant in regions of upwelling.

During the late early Miocene to early middle Miocene, the Owen Ridge was uplifted to a sufficient height as to be above the realm of turbidite deposition. Monsoonal-induced upwelling appears to have been initiated during the early late Miocene as reflected by increased amounts of biogenic silica preserved in the sediments. Sudden increases in the abundances of the planktonic foraminifers, Globigerina bulloides and Globorotalia menardii, and the appearance of the Neogloboquadrina acostaensis- $N$. humerosa-N. dutertrei group occur between Zones N15 and $\mathrm{N} 16$ at Site 721 . This change in the fauna may represent the initiation of the monsoonal-related intensity in the earliest late Miocene. According to Bé (1977), the modern representatives of these taxa are indicative of upwelling. The upwelling is probably also responsible for the comparative scarcity of warm-water Pli- 


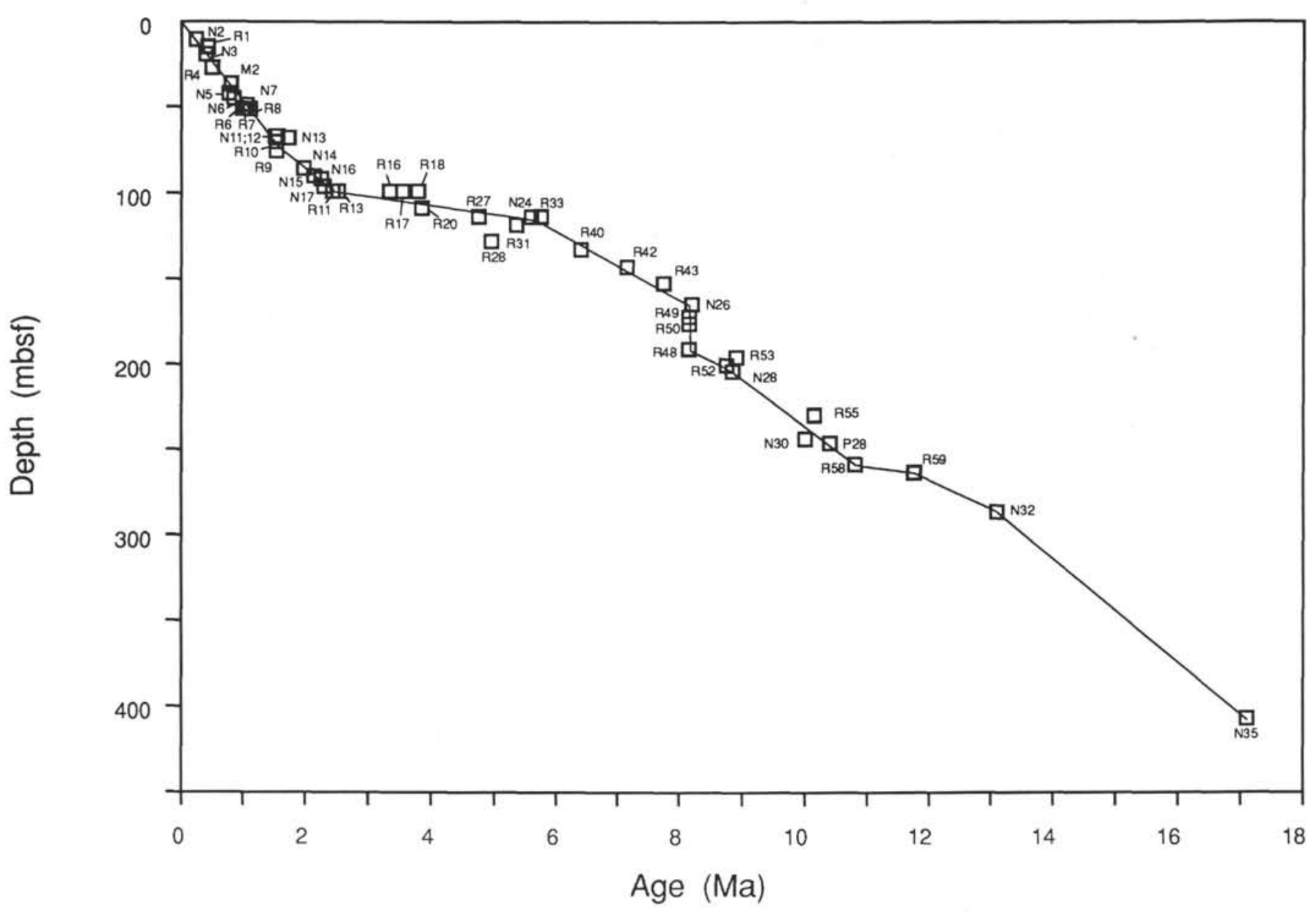

Figure 6. Sedimentation rate curve for Site 731 .

ocene calcareous nannofossils at Sites 721 and 722. Upper Miocene and Pliocene nannofloras are less diverse at Site 731 than the same age assemblages from Sites 721 and 722 . Also, at all three Owen Ridge sites, Coccolithus pelagicus, a typical coldwater nannofossil is dominant in the upper Pliocene and lower Pleistocene sediments.

Sites 726 and 729 were located in basins that were probably less than $130 \mathrm{~m}$ deep during the Eocene. Unfortunately, the Oligocene history of the Oman Margin remains unknown. The first occurrence of siliceous microfossils, presumably the result of the initiation of monsoonal-induced upwelling, in the middle Miocene sediments on the Oman Margin is earlier than on the Owen Ridge.

The presence (or absence) of certain microfossils in the Neogene and Quaternary sediments on the Oman Margin reflects the continued influence of the upwelling on the Neogene and Quaternary microfossil assemblages in the western Arabian Sea. These include the presence of both Reticulofenestra pseudoumbilica and $R$. gelida in sediments from calcareous nannofossil Zones NN11 through NN15. Common biogenic opal in upper Miocene sediments at Site 728 also are indicators of increased paleoproductivity resulting from the upwelling of nutrient-enriched waters.

Planktonic foraminifers indicative of upwelling, Hyalinea balthica, a cold-water benthic foraminifer, and Coccolithus pelagicus and Helicosphaera spp., and biogenic opal are all common components of Pliocene sediments. Coccolithus pelagicus continued to be abundant into the early Pleistocene.
Radiolarians which are characteristic of the Arabian Upwelling Assemblage, the benthic foraminifer Hyalinea balthica, and planktonic foraminifers indicative of upwelling also occur in Pleistocene sediments on the Oman Margin.

Sites 724 and 728 have undergone subsidence of $250 \mathrm{~m}$ and $1000 \mathrm{~m}$, respectively, since the early Pliocene. Site 725 has been uplifted during the latest Pleistocene to Holocene. The high $\mathrm{P} / \mathrm{B}$ ratio and the uniform benthic foraminiferal assemblages indicate that there have been no significant changes in the water depth at Site 727 during the Neogene or Quaternary.

An interesting transition in the upwelling regime took place between the Pliocene and the Pleistocene. While the Miocene and Pliocene sediments are dominated by the siliceous component, the Pleistocene sediments seem to be dominated by the calcareous component. Sites 721 and 731 are the only ones which contain large amounts of siliceous microfossils in the Pleistocene deposits.

\section{REFERENCES}

Auras-Schudnagies, A., Kroon, D., Ganssen, G. M., Hemleben, C., and van Hinte, J. E., in press. Biogeographic evidence from planktic foraminifers and pteropods for Red Sea anti-monsoonal surface currents. Deep-Sea Res. Part A.

Backman, J., 1980. Miocene-Pliocene nannofossils and sedimentation rates in the Hatton-Rockall Basin, NE Atlantic Ocean. Stockholm Contrib. Geol., 36:1-91.

Bé, A.W.H., 1977. An ecological, zoogeographic and taxonomic review of Recent planktonic foraminifera. In Ramsay, A. (Ed.), Oceanic Micropaleontology (Vol. 1): London (Academic Press), 1-100. 
Berggren, W. A., Kent, D. V., and Van Couvering, J. A., 1985. The Neogene: Part 2. Neogene geochronology and chronostratigraphy. In Snelling, N. J. (Ed.), The Chronology of the Geological Record. Geol. Soc. London Mem., 10:211-260.

Blow, W. H., 1969. Late middle Eocene to Recent planktonic foraminiferal biostratigraphy. In Brönniman, P., and Renz, H. H., (Eds.), Proc. First Intern. Conf. Planktonic Microfossils, Geneva: Leiden (E. J. Brill), 1:199-422.

Dowsett, H. J., 1989. Application of the graphic correlation method to Pliocene marine sequences. Mar. Micropaleontol., 14:3-32.

Hills, S. J., and Thierstein, H. R., 1989. Plio-Pleistocene calcareous plankton biochronology. Mar. Micropaleontol., 14:67-96.

Johnson, D. A., and Nigrini, C., 1982. Radiolarian biogeography in surface sediments of the eastern Indian Ocean. Mar. Micropaleontol., 7:237-281.

1985. Synchronous and time-transgressive Neogene radiolarian datum levels in the equatorial Indian and Pacific Oceans. Mar. Micropaleontol., 9:489-523.

Johnson, D. A., Schneider, D. A., Nigrini, C. A., Caulet, J. P., and Kent, J. V., 1989. Pliocene-Pleistocene radiolarian events and magnetostratigraphic correlations for the tropical Indian Ocean. Mar. Micropaleontol., 14:33-66.

Kroon, D., 1988. Distribution of extant planktic foraminiferal assemblages in Red Sea and northern Indian Ocean surface waters. In Brummer, G.J.A., and Kroon, D. (Eds.), Planktonic Foraminifers as Tracers of Ocean-Climate History: Amsterdam (Free Univ. Press), 229-270.

Martini, E., 1967. Nannoplankton und umlagerungserscheinungen im Persischen Golf und im nordichen Arabischen Meer. N. Jahrb. Geol. Palaont. Mh., 10:579-607.

1971. Standard Tertiary and Quaternary calcareous nannoplankton zonation. In Farinacci, A. (Ed.), Proc. 2nd Planktonic Conf. Roma: Rome (Ed. Technosci.), 2:739-785.

Murray, J. W., 1976. Comparative studies of living and dead benthic foraminiferal distributions. In Hedley, R. H., and Adams, C. G. (Eds), Foraminifera (Vol. 2): London (Academic Press), 45-109.

Nigrini, C., 1968. Radiolaria from eastern tropical Pacific sediments. Micropaleontology, 14:51-63.

, 1971. Radiolarian zonation in the Quaternary of the equatorial Pacific Ocean. In Funnell, B. M., and Riedel, W. R. (Eds.), The Micropaleontology of Oceans: Cambridge (Cambridge Univ. Press), 443-461.

Perch-Nielsen, K., 1985. Cenozoic calcareous nannofossils. In Bolli, H. M., Saunders, J. B., and Perch-Nielsen, K. (Eds.), Plankton Stratigraphy: Cambridge (Cambridge Univ. Press), 427-554.

Riedel, W. R., and Sanfilippo, A., 1978. Stratigraphy and evolution of Cenozoic radiolarians. Micropaleontology, 24:61-96.

Sanfilippo, A., Westberg-Smith, M. J., and Riedel, W. R., 1985. Cenozoic radiolaria. In Bolli, H. M., Saunders, J. B., and Perch-Nielsen, K. (Eds.), Plankton Stratigraphy: Cambridge (Cambridge Univ. Press), 631-712.

Shackleton, N. J., and Opdyke, N. D., 1977. Oxygen isotope and palaeomagnetic evidence for early Northern Hemisphere glaciation. Nature, 270:216-219.

Shipboard Scientific Party, 1989. Site 731. In Prell, W. L., Niitsuma, N., et al., 1989. Proc. ODP, Init. Repts., 117: College Station, TX (Ocean Drilling Program), 585-652.

Takayama, T., 1972. A note on the distribution of Braarudosphaera bigelowi (Gran and Braarud) Deflandre in the bottom sediments of Sendai Bay, Japan. Paleontol. Soc. Japan, Trans. Proc. N. S., 87:429435.

Takayama, T., and Sato, T., 1986. Coccolith biostratigraphy of the North Atlantic Ocean, Deep Sea Drilling Project Leg 94. In Ruddiman, W. F., Kidd, R. B., Thomas, E., et al., Init. Repts. DSDP, 94 (Pt. 2): Washington (U.S. Govt. Printing Office), 651-702.

van Morkhoven, F.P.C.M., Berggren, W. A., and Edwards, A. S., 1986. Cenozoic cosmopolitan deep-water benthic foraminifera. Bull. Cent. Rech. Explor.-Prod. Elf-Aquitaine, Mem. 11.

Date of initial receipt: 19 February 1990

Date of acceptance: 11 July 1990

Ms 117B-186
Table 5. Biostratigraphic and paleomagnetic events at Site 731.

\begin{tabular}{|c|c|c|c|}
\hline & & Event & $\begin{array}{c}\text { Hole } 731 \mathrm{~A} \text { deptr } \\
\text { (mbsf) }\end{array}$ \\
\hline \multicolumn{4}{|c|}{ Calcareous nannofossils } \\
\hline $\mathrm{N} 2$ & $\mathrm{~T}$ & Emiliania huxleyi & $9.80-10.95$ \\
\hline N3 & $\mathrm{T}$ & Pseudoemiliania lacunosa & $18.45-19.30$ \\
\hline N5 & $\mathrm{T}$ & Reticulofenestra asanoi & $40.95-42.45$ \\
\hline & B & Gephyrocapsa parallela & $43.95-45.45$ \\
\hline N7 & B & acme Reticulofenestra asanoi & $47.80-48.95$ \\
\hline & $\mathrm{T}$ & Gephyrocapsa (large) & $51.95-53.45$ \\
\hline N11 & $\mathbf{T}$ & Calcidiscus macintyrei & $65.95-67.00$ \\
\hline N12 & B & Gephyrocapsa oceanica & $65.95-67.00$ \\
\hline $\mathrm{N} 13$ & B & Gephyrocapsa caribbeanica & $67.00-68.15$ \\
\hline N14 & $\mathrm{T}$ & Discoaster brouweri & $83.85-86.40$ \\
\hline N15 & B & acme Gephyrocapsa & $89.05-90.55$ \\
\hline N16 & $\mathrm{T}$ & acme Crenalithus doronicoides & $90.55-92.05$ \\
\hline N17 & $\mathrm{T}$ & Discoaster pentaradiatus & $95.05-96.00$ \\
\hline $\mathrm{N} 24$ & $\mathrm{~T}$ & Discoaster quinqueramus & $112.85-114.35$ \\
\hline $\mathrm{N} 26$ & B & Discoaster quinqueramus & $163.70-165.05$ \\
\hline N28 & $\mathrm{T}$ & Discoaster hamatus & $202.50-205.11$ \\
\hline N30 & B & Discoaster hamatus & $241.30-245.47$ \\
\hline N31 & B & Catinaster coalitus & $256.10-260.60$ \\
\hline N32 & B & Discoaster kugleri & $282.55-289.60$ \\
\hline N33 & B & Cyclicargolithus floridamus & $289.60-291.42$ \\
\hline N35 & $\mathrm{T}$ & Sphenolithus belemnos & $404.95-409.00$ \\
\hline \multicolumn{4}{|c|}{ Planktonic foraminifer } \\
\hline P28 & $\mathbf{T}$ & Globorotalia mayeri & $241.30-250.90$ \\
\hline \multicolumn{4}{|c|}{ Radiolarians } \\
\hline R1 & $\mathrm{T}$ & Stylatractus universus & $9.80-19.30$ \\
\hline R3 & B & Collosphaera tuberosa & $24.65-28.80$ \\
\hline R4 & $\mathrm{T}$ & Pterocorys camapanula & $28.80-34.15$ \\
\hline R5 & B & Pterocorys hertwigii & $34.15-38.30$ \\
\hline R6 & $\mathrm{T}$ & Anthocyrtidium angulare & $47.80-53.15$ \\
\hline R7 & B & Lamprocyrtis nigriniae & $47.80-53.15$ \\
\hline R8 & $\mathrm{T}$ & Lamprocyrtis neoheteroporos & $47.80-53.15$ \\
\hline R10 & B & Anthocyrtidium angulare & $67.00-72.35$ \\
\hline R12 & B & Theocorythium trachelium & $67.00-72.35$ \\
\hline R9 & $\mathrm{T}$ & Pterocanium prismatium & $72.35-76.70$ \\
\hline R15 & $\mathrm{T}$ & Phormostichoartus fistula & $82.05-86.40$ \\
\hline R11 & B & Cycladophora davisiana & $96.00-101.35$ \\
\hline$R 13$ & B & Lamprocyrtis neoheteroporos & $96.00-101.35$ \\
\hline R14 & $\mathrm{T}$ & Stichocorys peregrina & $96.00-101.35$ \\
\hline R16 & $\mathrm{T}$ & Lychnodictyum audax & $96.00-101.35$ \\
\hline R17 & $\mathrm{T}$ & Phormostichoartus doliolum & $96.00-101.35$ \\
\hline R18 & B & Amphirhopalum ypsilon & $96.00-101.35$ \\
\hline R24 & $\mathrm{T}$ & Spongodiscus ambus & $101.35-105.70$ \\
\hline R20 & B & Spongaster tetras tetras & $105.70-111.05$ \\
\hline R21 & $\mathrm{T}$ & Spongaster berminghami & $105.70-111.05$ \\
\hline R26 & $\mathrm{T}$ & Didymocyrtis penultima & $105.70-111.05$ \\
\hline R23 & $\mathrm{T}$ & Dictyophimus splendens & $111.05-115.40$ \\
\hline R27 & $\mathrm{T}$ & Solenosphaera omnitubus & $111.05-115.40$ \\
\hline R29 & $\mathrm{T}$ & Siphostichartus corona & $111.05-115.40$ \\
\hline R30 & $\mathrm{T}$ & Stichocorys delmontensis & $111.05-115.40$ \\
\hline R33 & $\mathrm{T}$ & Stichocorys johnsoni & $111.05-115.40$ \\
\hline R31 & $\mathrm{T}$ & Acrobotrys tritubus & $115.40-120.70$ \\
\hline R36 & B & Spongodiscus ambus & $115.40-120.70$ \\
\hline R35 & & $S$. delmontensis $\rightarrow S$. peregrina & $115.40-125.00$ \\
\hline R37 & $\mathrm{T}$ & Calocycletta caepa & $120.70-125.00$ \\
\hline R28 & $\mathrm{T}$ & Botryostrobus bramlettei & $125.00-130.35$ \\
\hline R41 & B & Stichocorys peregrina & $125.00-130.35$ \\
\hline R39 & $\mathbf{T}$ & Dendrospyris bursa & $125.00-130.35$ \\
\hline R34 & $\mathbf{T}$ & Didymocyrtis antepenultima & $125.00-134.70$ \\
\hline R40 & B & Solenosphaera omnitubus & $130.35-134.70$ \\
\hline R42 & $\mathrm{T}$ & Diartus hughesi & $140.95-144.40$ \\
\hline R43 & B & Acrobotrys tritubus & $149.75-154.00$ \\
\hline R45 & $\mathbf{T}$ & Dictyocoryne ontongensis & $149.75-154.00$ \\
\hline R49 & $\mathbf{T}$ & Botryostrobus miralestensis & $169.05-173.40$ \\
\hline R50 & $\mathbf{T}$ & Diartus petterssoni & $173.40-178.75$ \\
\hline R46 & $\mathrm{T}$ & Didymocyrtis laticonus & $178.75-183.10$ \\
\hline R51 & & D. petterssoni $\rightarrow D$. hughesi & $178.75-198.15$ \\
\hline R48 & $T$ & Stichocorys wolffii & $188.45-192.80$ \\
\hline R53 & B & Botryostrobus bramlettei & $192.80-198.15$ \\
\hline R52 & & Diartus hughesi & $198.15-202.50$ \\
\hline R54 & & Dictyocoryne ontongensis & $198.15-202.50$ \\
\hline R55 & $\mathrm{T}$ & Cyrtocapsella japonica & $227.25-231.60$ \\
\hline R58 & $\mathrm{T}$ & Lithopera thornburgi & $256.27-260.60$ \\
\hline R59 & $\mathrm{T}$ & Cyrtocapsella cornuta & $260.60-265.96$ \\
\hline \multicolumn{4}{|c|}{ Polarity reversals } \\
\hline M1 & & Brunhes/Matuyama(?) & $35.25-36.75$ \\
\hline M2 & $\mathrm{T}$ & Jaramillo(?) & $38.23-38.75$ \\
\hline M3 & B & Jaramillo & $45.45-46.25$ \\
\hline
\end{tabular}




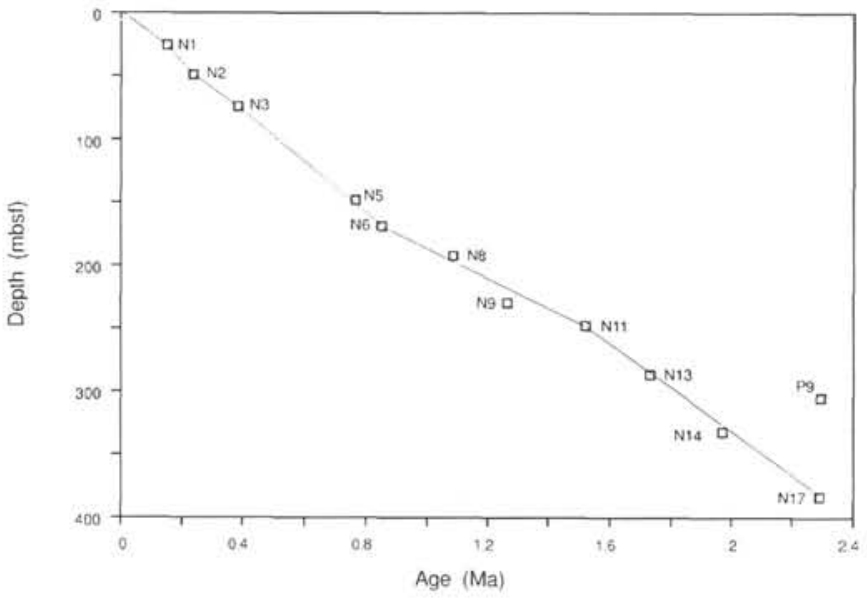

Figure 7. Sedimentation rate curve for Site 723.

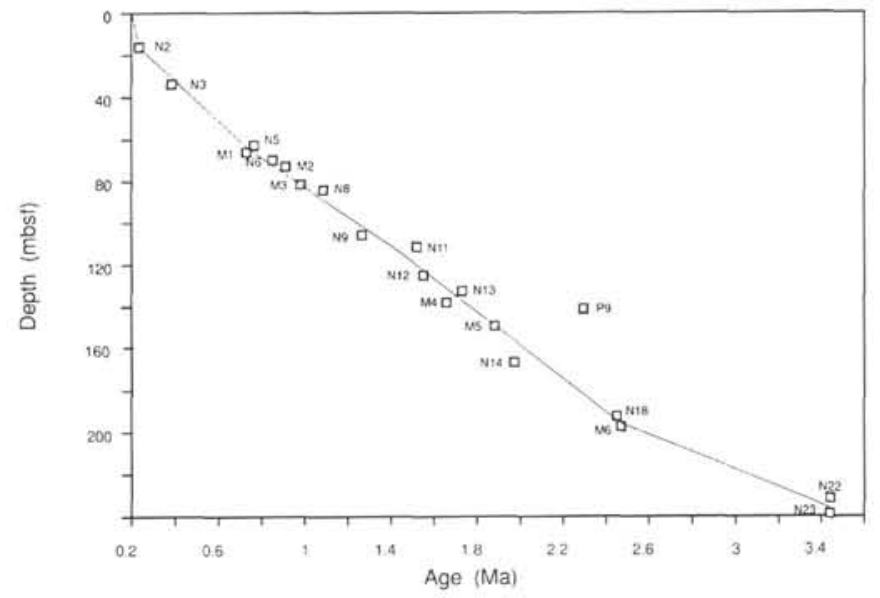

Figure 8. Sedimentation rate curve for Site 724.

Table 6. Biostratigraphic events at Site 723.

\begin{tabular}{|c|c|c|c|}
\hline & & Event & $\begin{array}{l}\text { Hole } 723 \mathrm{~A} \text { depth } \\
\text { (mbsf) }\end{array}$ \\
\hline \multicolumn{4}{|c|}{ Calcareous nannofossils } \\
\hline N1 & $\mathrm{T}$ & Helicosphaera inversa & $24.70-27.10$ \\
\hline N2 & B & Emiliania huxleyi & $47.60-50.60$ \\
\hline N3 & $\mathbf{T}$ & Pseudoemiliania lacunosa & $73.00-75.40$ \\
\hline N5 & $\mathrm{T}$ & Reticulofenestra asanoi & $143.10-153.70$ \\
\hline N6 & B & Gephyrocapsa parallela & $162.40-173.30$ \\
\hline N8 & $\mathrm{T}$ & Gephyrocapsa (large) & $191.40-192.74$ \\
\hline N9 & $\mathrm{T}$ & Helicosphaera sellii & $227.58-231.27$ \\
\hline N11 & $\mathrm{T}$ & Calcidiscus macintyrei & $245.87-249.40$ \\
\hline $\mathrm{N} 13$ & B & Gephyrocapsa caribbeanica & $285.19-287.90$ \\
\hline N14 & $\mathbf{T}$ & Discoaster brouweri & $330.36-333.53$ \\
\hline N17 & $\mathrm{T}$ & Discoaster pentaradiatus & $381.50-384.68$ \\
\hline
\end{tabular}

Planktonic foraminifers

P9 T Globigerinoides obliqus $\quad 302.65-307.10$

Table 7. Biostratigraphic and paleomagnetic events at Site 724.

\begin{tabular}{|c|c|c|c|c|}
\hline & & Event & $\begin{array}{l}\text { Hole 724A depth } \\
\text { (mbsf) }\end{array}$ & $\begin{array}{c}\text { Hole 724B depth } \\
\text { (mbsf) }\end{array}$ \\
\hline \multicolumn{5}{|c|}{ Calcareous nannofossils } \\
\hline N2 & B & Emiliania huxleyi & $15.90-16.95$ & \\
\hline N3 & $\mathrm{T}$ & Pseudoemiliania lacunosa & $32.45-34.90$ & \\
\hline N5 & $\mathrm{T}$ & Reticulofenestra asanoi & & $60.25-65.50$ \\
\hline N6 & B & Gephyrocapsa parallela & & $68.50-71.40$ \\
\hline N8 & $T$ & Gephyrocapsa (large) & & $83.70-84.75$ \\
\hline N9 & $\mathrm{T}$ & Helicosphaera sellii & & $104.35-107.35$ \\
\hline N11 & $\mathrm{T}$ & Calcidiscus macintyrei & & $110.00-112.70$ \\
\hline $\mathrm{N} 12$ & B & Gephyrocapsa oceanica & & $123.50-126.44$ \\
\hline N13 & B & Gephyrocapsa caribbeanica & & $132.00-133.03$ \\
\hline N14 & $\mathrm{T}$ & Discoaster brouweri & & $165.21-168.05$ \\
\hline N18 & $\mathbf{T}$ & Discoaster surculus & & $191.05-194.05$ \\
\hline $\mathrm{N} 22$ & $\mathrm{~T}$ & Sphenolithis abies & & $230.05-233.05$ \\
\hline $\mathrm{N} 23$ & $\mathrm{~T}$ & Reticulofenestra pseudoumbilica & & $238.40-239.44$ \\
\hline
\end{tabular}

Planktonic foraminifer

P9 T Globigerinoides obliquus

$146.85-151.40$

Polarity reversals

$$
\begin{array}{lll}
\text { M1 } & & \text { Brunhes/Matuyama } \\
\text { M2 } & \text { T } & \text { Jaramillo } \\
\text { M3 } & \text { B } & \text { Jaramillo } \\
\text { M4 } & \text { T } & \text { Olduvai } \\
\text { M5 } & \text { B } & \text { Olduvai } \\
\text { M6 } & & \text { Matuyama/Gauss }
\end{array}
$$

65.45-66.95

71.34-74.44

$81.14-81.93$

$134.18-141.89$

$148.86-149.70$ 194.23-200.36 


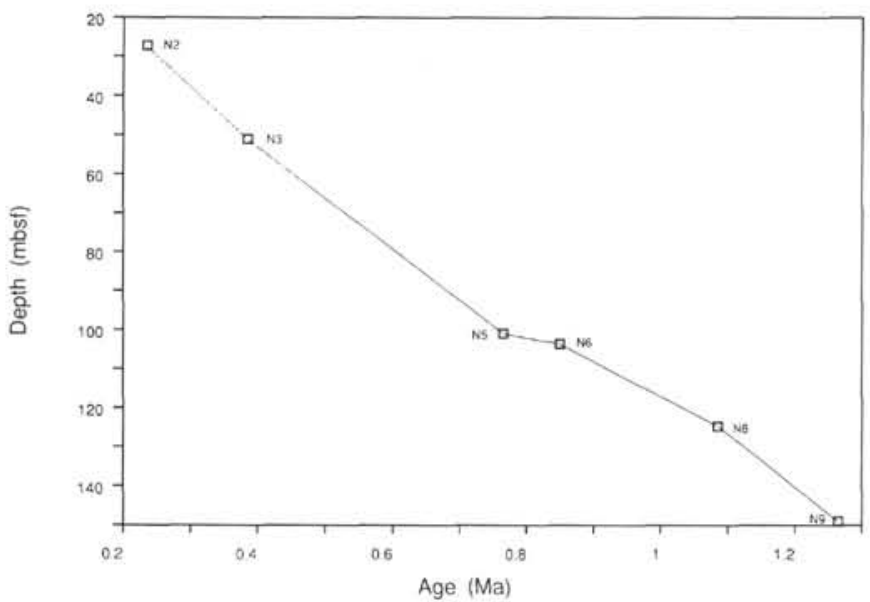

Figure 9. Sedimentation rate curve for Site 725.

Table 8. Biostratigraphic events at Site 725.

\begin{tabular}{|c|c|c|}
\hline & Event & $\begin{array}{l}\text { Hole 725C depth } \\
\text { (mbsf) }\end{array}$ \\
\hline \multicolumn{3}{|c|}{ Calcareous nannofossils } \\
\hline $\mathrm{N} 2 \mathrm{~B}$ & 3 Emiliania huxleyi & $25.78-28.50$ \\
\hline N3 $\mathrm{T}$ & Pseudoemiliania lacunosa & $50.18-51.68$ \\
\hline N5 $T$ & Reticulofenestra asanoi & $99.48-102.23$ \\
\hline N6 B & 3 Gephyrocapsa parallela & $102.23-104.90$ \\
\hline N8 $\mathrm{T}$ & Gephyrocapsa (large) & $124.10-125.28$ \\
\hline N9 $T$ & T Helicosphaera sellii & $144.89-153.20$ \\
\hline
\end{tabular}

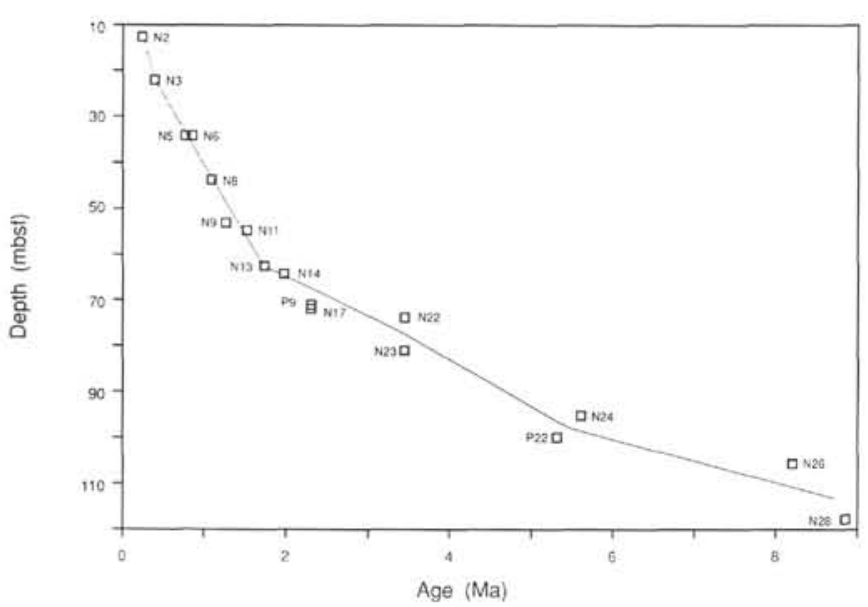

Figure 10. Sedimentation rate curve for Site 726.
Table 9. Biostratigraphic events at Site 726.

\begin{tabular}{|c|c|c|c|}
\hline & & Event & $\begin{array}{l}\text { Hole 726A depth } \\
\text { (mbsf) }\end{array}$ \\
\hline \multicolumn{4}{|c|}{ Calcareous nannofossils } \\
\hline N2 & & Emiliania huxleyi & $11.08-14.08$ \\
\hline & $\mathrm{T}$ & Pseudoemiliania lacunosa & $20.48-23.48$ \\
\hline N5 & $\mathbf{T}$ & Reticulofenestra asanoi & $32.98-35.30$ \\
\hline & B & Gephyrocapsa parallela & $32.98-35.30$ \\
\hline N8 & $\mathrm{T}$ & Gephyrocapsa (large) & $42.48-44.70$ \\
\hline N9 & $\mathrm{T}$ & Helicosphaera sellii & $51.88-54.10$ \\
\hline N11 & $\mathrm{T}$ & Calcidiscus macintyrei & $54.10-55.28$ \\
\hline N13 & B & Gephyrocapsa caribbeanica & $61.28-63.60$ \\
\hline N14 & $\mathrm{T}$ & Discoaster brouweri & $63.60-64.78$ \\
\hline N17 & $\mathrm{T}$ & Discoaster pentaradiatus & $70.63-73.20$ \\
\hline $\mathrm{N} 22$ & $\mathrm{~T}$ & Sphenolithus abies & $73.20-74.38$ \\
\hline $\mathrm{N} 23$ & $\mathrm{~T}$ & Reticulofenestra pseudoumbilica & $77.85-83.98$ \\
\hline $\mathrm{N} 24$ & $\mathrm{~T}$ & Discoaster quinqueramus & $93.58-96.58$ \\
\hline $\mathrm{N} 25$ & $\mathrm{~T}$ & Discoaster berggrenii & $93.58-96.58$ \\
\hline N26 & B & Discoaster quinqueramus & $98.10-113.24$ \\
\hline N27 & B & Discoaster berggrenii & $98.10-113.24$ \\
\hline N28 & & Discoaster hamatus & $116.24-119.24$ \\
\hline
\end{tabular}

Planktonic foraminifers

P9 T Globigerinoides obliquus

P22 B Globorotalia tumida tumida

68.75-73.20

97.55-102.10

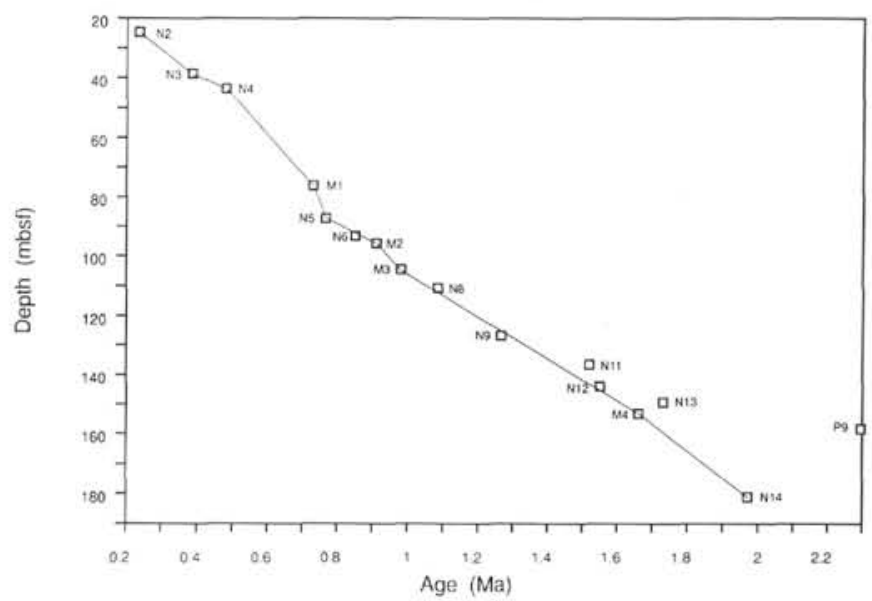

Figure 11. Sedimentation rate curve for Site 727. 
Table 10. Biostratigraphic and paleomagnetic events at Site 727.

\begin{tabular}{ccc}
\hline \multicolumn{1}{c}{ Event } & $\begin{array}{c}\text { Hole } \\
\text { 724A depth } \\
\text { (mbsf) }\end{array}$ \\
\hline Calcareous nannofossils \\
N2 & B Emiliania huxleyi & \\
N3 & T Pseudoemiliania lacunosa & $23.08-26.08$ \\
N4 & B Helicosphaera inversa & $41.80-38.98$ \\
N5 & T Reticulofenestra asanoi & $85.80-88.78$ \\
N6 & B Gephyrocapsa parallela & $91.70-94.70$ \\
N8 & T Gephyrocapsa (large) & $109.18-112.15$ \\
N9 & T Helicosphaera sellii & $125.18-128.14$ \\
N11 & T Calcidiscus macintyrei & $134.96-138.06$ \\
N12 & B Gephyrocapsa oceanica & $143.06-144.78$ \\
N13 & B Gephyrocapsa caribbeanica & $147.78-150.74$ \\
N14 & T Discoaster brouweri & $179.90-182.40$
\end{tabular}

Planktonic foraminifer

P9 T Globigerinoides obliqus $\quad 153.30-163.00$

Polarity reversals

$\begin{array}{lllc}\text { M1 } & & \text { Brunhes/Matuyama } & 75.80-76.50 \\ \text { M2 } & \text { T } & \text { Jaramillo } & 95.40-95.83 \\ \text { M3 } & \text { B } & \text { Jaramillo } & 104.14-104.69 \\ \text { M4 } & \text { T } & \text { Olduvai } & 152.72-153.55\end{array}$

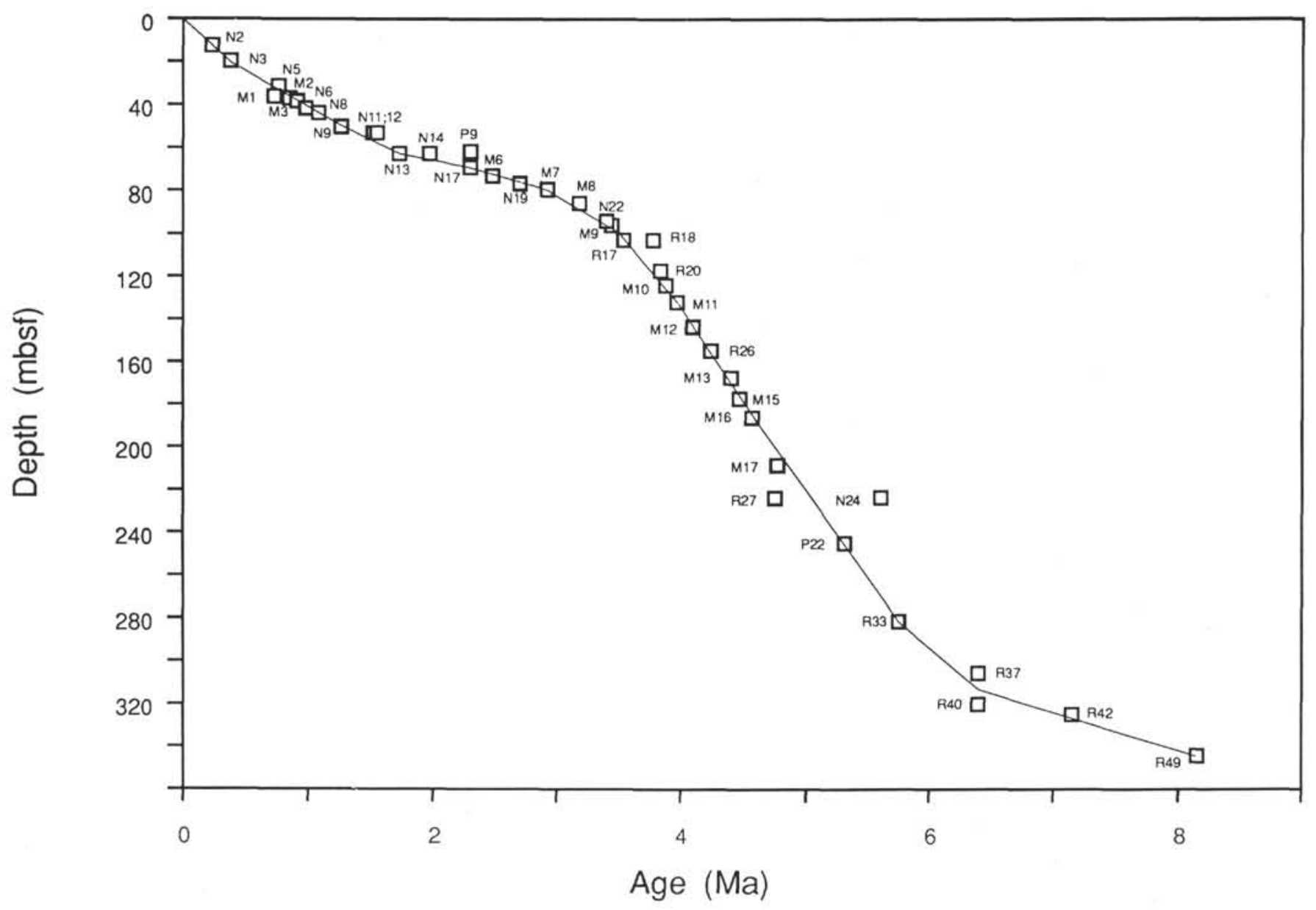

Figure 12. Sedimentation rate curve for Site 728. 
Table 11. Biostratigraphic and paleomagnetic events at Site 728.

\begin{tabular}{|c|c|c|c|}
\hline \multicolumn{3}{|r|}{ Event } & $\begin{array}{l}\text { Hole } 728 \mathrm{~A} \text { depth } \\
\text { (mbsf) }\end{array}$ \\
\hline \multicolumn{4}{|c|}{ Calcareous nannofossils } \\
\hline N2 & B & Emiliania huxleyi & $10.78-13.78$ \\
\hline N3 & $\mathrm{T}$ & Pseudoemiliania lacunosa & $19.10-20.28$ \\
\hline N5 & $\mathrm{T}$ & Reticulofenestra asanoi & $29.68-32.68$ \\
\hline N6 & B & Gephyrocapsa parallela & $35.68-38.00$ \\
\hline N8 & $\mathbf{T}$ & Gephyrocapsa (large) & $42.18-45.18$ \\
\hline N9 & $\mathrm{T}$ & Helicosphaera sellii & $48.68-51.68$ \\
\hline N11 & $\mathrm{T}$ & Calcidiscus macintyrei & $51.68-54.68$ \\
\hline $\mathrm{N} 12$ & B & Gephyrocapsa oceanica & $51.68-54.68$ \\
\hline $\mathrm{N} 13$ & B & Gephyrocapsa caribbeanica & $61.25-64.25$ \\
\hline $\mathrm{N} 14$ & $\mathrm{~T}$ & Discoaster brouweri & $61.25-64.25$ \\
\hline N17 & $\mathrm{T}$ & Discoaster pentaradiatus & $67.68-70.68$ \\
\hline N19 & $\mathrm{T}$ & Discoaster tamalis & $76.10-77.28$ \\
\hline $\mathrm{N} 22$ & $\mathrm{~T}$ & Sphenolithus abies & $95.30-96.48$ \\
\hline $\mathrm{N} 23$ & $\mathrm{~T}$ & Reticulofenestra pseudoumbilica & $95.30-96.48$ \\
\hline $\mathrm{N} 24$ & $\mathrm{~T}$ & Discoaster quinqueramus & $222.01-225.00$ \\
\hline
\end{tabular}

Planktonic foraminifers

$\begin{array}{lll}\text { P9 } & \text { T } & \text { Globigerinoides obliquus } \\ \text { P22 } & \text { B } & \text { Globorotalia tumida tumida }\end{array}$

Radiolarians

$\begin{array}{llll}\text { R17 } & \text { T } & \text { Phormostichoartus doliolum } & 100.65-104.90 \\ \text { R18 } & \text { B Amphirhopalum ypsilon } & 100.65-104.90 \\ \text { R20 } & \text { B Spongaster tetras tetras } & 114.50-119.85 \\ \text { R24 } & \text { T Spongodiscus ambus } & 139.25-143.50 \\ \text { R26 } & \text { T Didymocyrtis penultima } & 148.85-153.10 \\ \text { R27 } & \text { T Solenosphaera omnitubus } & 220.80-226.15 \\ \text { R29 } & \text { T Siphostichartus corona } & 245.45-249.80 \\ \text { R30 } & \text { T Stichocorys delmontensis } & 245.45-249.80 \\ \text { R33 } & \text { T Stichocorys johnsoni } & 278.80-284.15 \\ \text { R36 } & \text { B Spongodiscus ambus } & 288.50-293.82 \\ \text { R35 } & & \text { S. delmontensis } \rightarrow \text { S. peregrina } & 298.10-307.80 \\ \text { R37 } & \text { T Calocycletta caepa } & 303.45-307.80 \\ \text { R41 } & \text { B Stichocorys peregrina } & 313.15-317.50 \\ \text { R40 } & \text { B Solenosphaera omnitubus } & 317.50-322.85 \\ \text { R42 } & \text { T Diartus hughesi } & 322.85-327.20 \\ \text { R46 } & \text { T Didymocyrtis laticonus } & 342.15-346.40 \\ \text { R49 } & \text { T Botryocyrtis miralestensis } & 342.15-346.60\end{array}$

Polarity reversals

$\begin{array}{llll}\text { M1 } & & \text { Brunhes/Matuyama } \\ \text { M2 } & \text { T } & \text { Jaramillo } \\ \text { M3 } & \text { B } & \text { Jaramillo } \\ \text { M6 } & & \text { Matuyama/Gauss } \\ \text { M7 } & \text { T } & \text { Kaena } \\ \text { M8 } & \text { B } & \text { Mammoth } \\ \text { M9 } & & \text { Gauss/Gilbert } \\ \text { M10 } & \text { T } & \text { Cochiti } \\ \text { M11 } & \text { B } & \text { Cochiti } \\ \text { M12 } & \text { T } & \text { Nunivak } \\ \text { M13 } & \text { B } & \text { Nunivak } \\ \text { M14 } & \text { T } & \text { Sidufjall } \\ \text { M15 } & \text { B } & \text { Sidufjall } \\ \text { M16 } & \text { T } & \text { Thvera } \\ \text { M17 } & \text { B } & \text { Thvera }\end{array}$

$35.70-36.45$

37.95-38.45

$40.72-42.20$

$72.20-73.70$

$78.80-79.55$

84.80-86.15

92.90-93.65

$122.45-125.35$

$131.40-132.15$

$142.60-144.10$

$153.63-155.80$

167.08-167.79

$176.75-177.49$

$185.78-186.32$

207.84-208.70

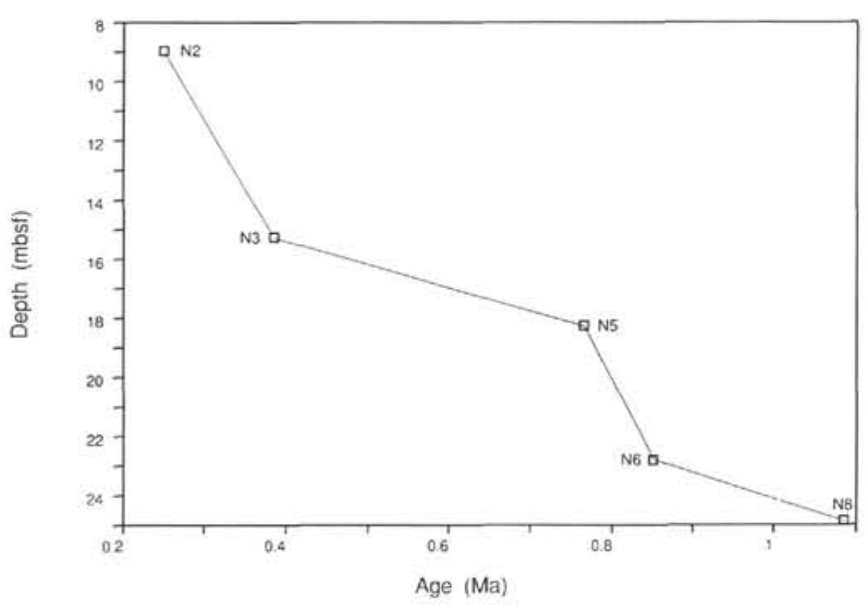

Figure 13. Sedimentation rate curve for Site 729.

Table 12. Biostratigraphic events at Site 729.

\begin{tabular}{|c|c|c|}
\hline & Event & $\begin{array}{c}\text { Hole 729A depth } \\
\text { (mbsf) }\end{array}$ \\
\hline \multicolumn{3}{|c|}{ Calcareous nannofossils } \\
\hline N2 $B$ & Emiliania huxleyi & $7.25-10.25$ \\
\hline N3 $T$ & Pseudoemiliania lacunosa & $13.75-16.75$ \\
\hline N5 $\mathrm{T}$ & Reticulofenestra asanoi & $16.75-19.75$ \\
\hline N6 B & Gephyrocapsa parallela & $22.30-23.35$ \\
\hline N8 $T$ & Gephyrocapsa (large) & $23.35-26.35$ \\
\hline
\end{tabular}

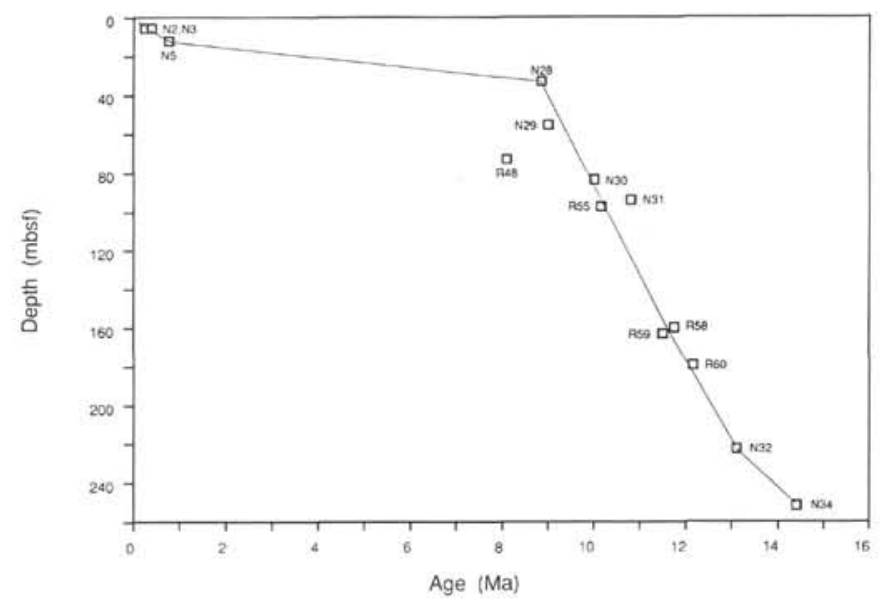

Figure 14. Sedimentation rate curve for Site 730 . 
Table 13. Biostratigraphic events at Site 730.

\begin{tabular}{|c|c|c|c|}
\hline & & Event & $\begin{array}{c}\text { Hole } 730 \mathrm{~A} \text { depth } \\
\text { (mbsf) }\end{array}$ \\
\hline \multicolumn{4}{|c|}{ Calcareous nannofossils } \\
\hline N2 & B & Emiliania huxleyi & $4.05-7.05$ \\
\hline N3 & $\mathrm{T}$ & Pseudoemiliamia lacunosa & $4.05-7.05$ \\
\hline N5 & $\mathrm{T}$ & Reticulofenestra asanoi & $11.91-12.31$ \\
\hline N28 & $T$ & Discoaster hamatus & $31.35-34.35$ \\
\hline $\mathrm{N} 29$ & $T$ & Catinaster coalitus & $53.35-56.85$ \\
\hline N30 & B & Discoaster hamatus & $82.25-84.90$ \\
\hline N31 & B & Catinaster coalitus & $91.95-95.65$ \\
\hline N32 & B & Discoaster kugleri & $221.25-224.25$ \\
\hline N33 & $\mathrm{T}$ & Cyclicargolithus floridanus & $221.25-224.25$ \\
\hline N34 & $\mathbf{T}$ & Sphenolithus heteromorphus & $250.25-253.25$ \\
\hline \multicolumn{4}{|c|}{ Planktonic foraminifers } \\
\hline P30 & $\mathbf{T}$ & Globorotalia fohsi & $162.20-164.35$ \\
\hline P32 & B & Orbulina universa & $291.55-297.60$ \\
\hline \multicolumn{4}{|c|}{ Radiolarians } \\
\hline R48 & $\mathbf{T}$ & Stichocorys wolffii & $70.85-75.20$ \\
\hline R55 & $\mathbf{T}$ & Cyrtocapsella japonica & $94.60-99.95$ \\
\hline R58 & $\mathrm{T}$ & Lithopera thornburgi & $152.60-157.95$ \\
\hline R59 & $\mathrm{T}$ & Cyrtocapsella cornuta & $157.95-162.20$ \\
\hline R56 & B & Diartus petterssoni & $167.55-171.90$ \\
\hline R60 & $\mathbf{T}$ & Lithopera renzae & $177.25-181.60$ \\
\hline
\end{tabular}

